\title{
Causes of interannual variability over the southern hemispheric tropospheric ozone maximum
}

\author{
Junhua Liu ${ }^{1,2}$, Jose M. Rodriguez ${ }^{2}$, Stephen D. Steenrod ${ }^{1,2}$, Anne R. Douglass ${ }^{2}$, Jennifer A. Logan ${ }^{3}$, Mark A. Olsen ${ }^{2,4}$, \\ Krzysztof Wargan $^{2,5}$, and Jerald R. Ziemke ${ }^{2,4}$ \\ ${ }^{1}$ Universities Space Research Association (USRA), GESTAR, Columbia, MD, USA \\ ${ }^{2}$ NASA Goddard Space Flight Center, Greenbelt, MD, USA \\ ${ }^{3}$ School of Engineering and Applied Sciences, Harvard University, Cambridge, MA, USA \\ ${ }^{4}$ Morgan State University, Baltimore, MD, USA \\ ${ }^{5}$ Science Systems and Applications, Inc., Lanham, MD, USA \\ Correspondence to: Junhua Liu (junhua.liu@ nasa.gov)
}

Received: 31 July 2016 - Discussion started: 10 October 2016

Revised: 2 February 2017 - Accepted: 8 February 2017 - Published: 7 March 2017

\begin{abstract}
We examine the relative contribution of processes controlling the interannual variability (IAV) of tropospheric ozone over four sub-regions of the southern hemispheric tropospheric ozone maximum (SHTOM) over a 20 -year period. Our study is based on hindcast simulations from the National Aeronautics and Space Administration Global Modeling Initiative chemistry transport model (NASA GMI-CTM) of tropospheric and stratospheric chemistry, driven by assimilated Modern Era Retrospective Analysis for Research and Applications (MERRA) meteorological fields. Our analysis shows that over SHTOM region, the IAV of the stratospheric contribution is the most important factor driving the IAV of upper tropospheric ozone $(270 \mathrm{hPa})$, where ozone has a strong radiative effect. Over the South Atlantic region, the contribution from surface emissions to the IAV of ozone exceeds that from stratospheric input at and below $430 \mathrm{hPa}$. Over the South Indian Ocean, the IAV of stratospheric ozone makes the largest contribution to the IAV of ozone with little or no influence from surface emissions at 270 and $430 \mathrm{hPa}$ in austral winter. Over the tropical South Atlantic region, the contribution from IAV of stratospheric input dominates in austral winter at $270 \mathrm{hPa}$ and drops to less than half but is still significant at $430 \mathrm{hPa}$. Emission contributions are not significant at these two levels. The IAV of lightning over this region also contributes to the IAV of ozone in September and December. Over the tropical southeastern Pacific, the contribution of the IAV of stratospheric input is significant at 270 and $430 \mathrm{hPa}$ in austral winter, and emissions have little influence.
\end{abstract}

\section{Introduction}

Tropospheric ozone plays a critical role in controlling the oxidative capacity of the troposphere through its photolysis in the presence of water vapor, generating hydroxyl radical $(\mathrm{OH})$, the main atmospheric oxidant (e.g., Logan et al., 1981). It contributes to smog and is harmful to human and ecosystem health near the surface. It acts as a greenhouse gas especially in the upper troposphere (Lacis et al., 1990) and affects the radiative forcing of the climate system. Tropospheric ozone is produced by photochemical oxidation of $\mathrm{CO}$ and volatile organic compounds (VOCs) in the presence of nitrogen oxides $\left(\mathrm{NO}_{x}\right)$ (e.g., Logan et al., 1981). Downward transport of ozone from the stratosphere is also an important source of tropospheric ozone (e.g., Danielsen, 1968; Stohl et al., 2003). Deep convection and long-range transport of ozone and its precursors also modulate the tropospheric $\mathrm{O}_{3}$ distributions (e.g., Chandra et al., 2009; Oman et al., 2011).

Our study is motivated by the presence of tropospheric ozone maximum over the tropical and subtropical Southern Hemisphere as seen both in model simulations and the Global Modeling and Assimilation Office (GMAO) assimilated ozone product derived from Ozone Monitoring Instrument (OMI) and Microwave Limb Sounder (MLS) satellite measurements (Fig. 1). Although in the Southern Hemisphere tropospheric air is relatively "clean" and less polluted compared with the Northern Hemisphere, this tropospheric ozone column maximum reaches as high as $35 \mathrm{DU}$ and is 

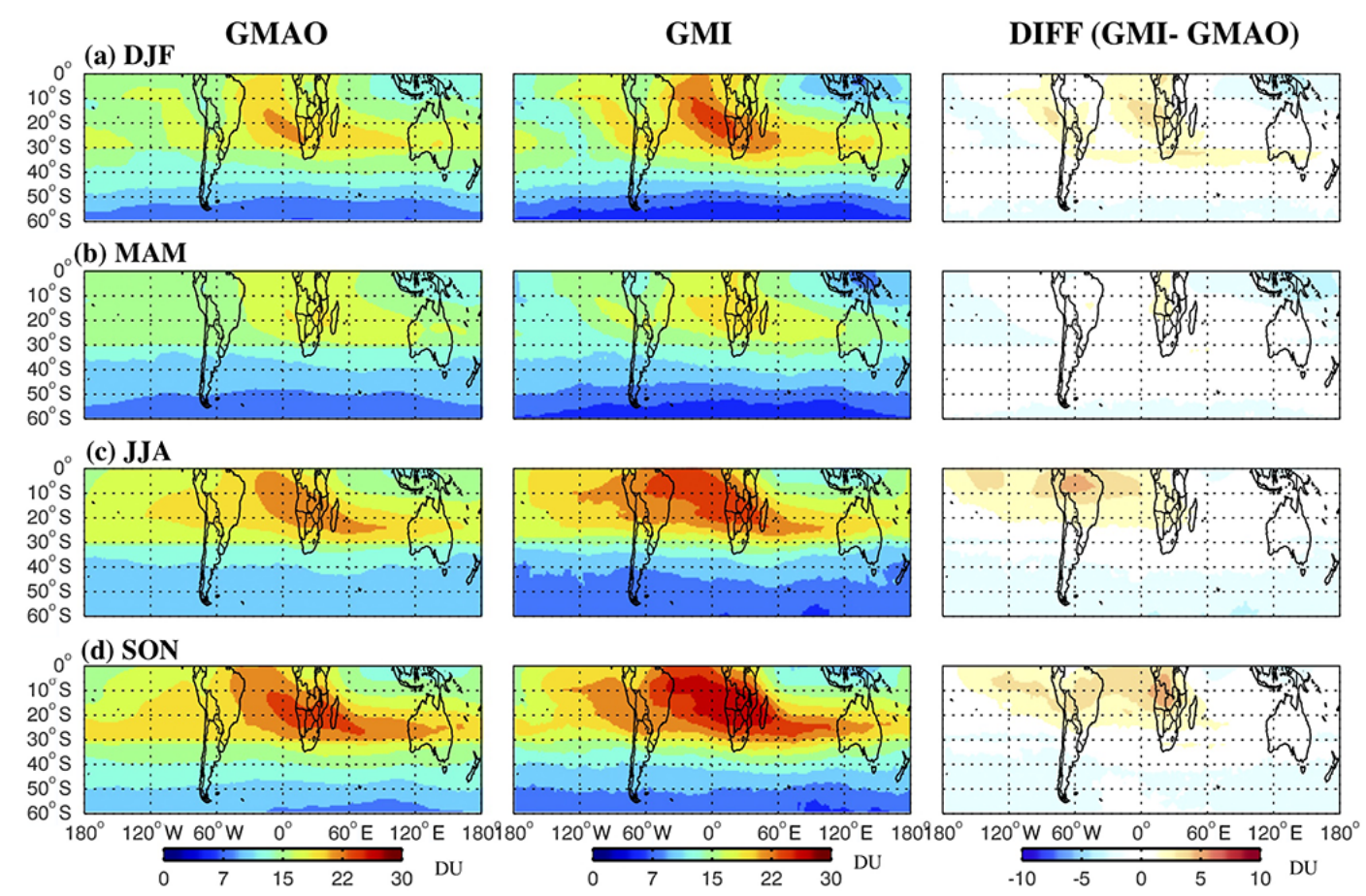

Figure 1. Seasonal climatology of upper tropospheric column ozone (UTOC, integrated from 500 hPa to the tropopause) (in Dobson units) for (a) December-January-February (DJF), (b) March-April-May (MAM), (c) June-July-August (JJA), and (d) September-OctoberNovember (SON) averaged from 2005 to 2012 for GMAO assimilated ozone (left) and GMI-CTM simulated ozone (middle) and their absolute difference (right). The GMAO assimilated ozone has been adjusted by adding $2.5 \mathrm{DU}$ in $0-30^{\circ} \mathrm{S}$ based on Wargan et al. (2015).

comparable to the typical northern mid-latitude values of $30 \mathrm{DU}$. The elevated tropospheric ozone column is centered over the South Atlantic from the Equator to $30^{\circ} \mathrm{S}$, and is part of the well-known tropical wave-one pattern first noted in observations made by the Nimbus 7 total ozone mapping spectrometer (TOMS) (e.g., Fishman et al., 1990; Ziemke et al., 1996). This ozone maximum extends westward to South America and the tropical southeastern Pacific, southeastward to southern Africa and the South Indian Ocean along the latitude band of $30-45^{\circ} \mathrm{S}$, and is a dominant global feature (Thompson et al., 2003; Sauvage et al., 2007). This elevated ozone region exists year-round, with a seasonal maximum in August-October, and a seasonal minimum in April-May.

This study provides an examination of the relative contributions of the factors that control the interannual variations of the southern hemispheric tropospheric ozone maximum over a 20 -year period. Prior studies have examined the processes that produce the southern hemispheric tropospheric ozone maximum (SHTOM), but consider only short periods or are limited in spatial scale. These studies concluded that horizontal and vertical transport of ozone precursors from regions of biomass burning (e.g., Jacob et al., 1996; Thompson et al., 1996; Pickering et al., 1996; Jenkins and Ryu, 2004b; Sauvage et al., 2006; Jourdain et al., 2007; Thouret et al., 2009), lightning $\mathrm{NO}_{x}$ (Martin et al., 2002; Jenkins and Ryu, 2004a; Kim et al., 2013; Tocquer et al., 2015), and stratospheric intrusions (Weller et al., 1996) all contribute to this tropospheric ozone column maximum. However, changes of the relative contributions of these factors to tropospheric ozone on interannual timescales over this region have not been examined in detail. Studies considering tropospheric ozone interannual variability have not focused on the SHTOM region. Hess and Mahowald (2009) used a chemistry transport model (CTM) to quantify relative interannual variability in global model ozone in hindcast simulations with constant emissions and prescribed stratospheric ozone. The CTM was driven by two sets of meteorological fields: (a) the National Center for Environmental PredictionNational Center for Atmospheric Research reanalysis and (b) from a simulation using the Community Atmosphere Model (CAM-3) forced with observed sea surface temperatures. Their study found that relative IAV of ozone at $500 \mathrm{hPa}$ shows the maximum between the Equator and $30^{\circ} \mathrm{S}$ in JuneJuly-August (JJA) and December-January-February (DJF). Zeng and Pyle (2005) used a climate-chemistry model to evaluate the ENSO effects on the interannual variability of tropospheric ozone. Their study concludes that stratospheretroposphere exchange (STE) variation induced by ENSO is one important factor driving the IAV of the global mean of tropospheric ozone. Voulgarakis et al. (2010) examined the drivers of interannual variability of the global tropospheric ozone using the p-TOMCAT tropospheric CTM. Their study 
shows that changing transport including the STE is important in determining the IAV of tropospheric ozone. Voulgarakis et al. (2011) demonstrated that increases in the amounts of stratospheric ozone entering the troposphere following El Niño events are mainly driven by changes in the STE. The influence of emissions is confined to areas of intense burning on the interannual timescale. Murray et al. (2013) examined the effects of lightning on the IAV in the tropical tropospheric ozone column based on the GEOS-Chem CTM with IAV in tropical lightning constrained by satellite observations from lightning imaging sensors (LISs). Their study finds that lightning plays an important role in driving the IAV of tropical tropospheric ozone column, especially over eastern Africa, central Brazil, and in continental outflow in the eastern Pacific and the Atlantic, but their model does not reproduce the IAV in tropospheric column ozone (TCO) except in eastern Africa and central Brazil. Liu et al. (2016) analyzed simulations from a global chemistry and transport model to show that the IAV in the stratospheric contribution significantly affects the IAV of upper tropospheric ozone at the SHADOZ station over Réunion $\left(21^{\circ} \mathrm{S}, 55^{\circ} \mathrm{E}\right)$. In this study, we focus on the SHTOM region and quantify the relative contributions of several factors to the tropospheric ozone interannual variability during the past 20 years. We examine the horizontal and vertical variations of these contributions by separating the SHTOM into four sub-regions and comparing their IAVs at two selected levels (270 and $430 \mathrm{hPa}$ ). This analysis distinguishes between anthropogenic and natural sources on the IAV of the tropospheric ozone and their contributions to the radiative forcing changes.

In this study, we use a global CTM to identify the processes impacting observed interannual variability of the tropospheric ozone column maximum in the Southern Hemisphere. We examine the model sensitivity of tropospheric ozone to different ozone sources through the use of multiple linear regression. We include stratospheric input and emissions as two major predictor variables in our regression. We include the lightning $\mathrm{NO}_{x}$ as the third factor in our regression model over the tropical South Atlantic region, where ozone is sensitive to the IAV of lightning $\mathrm{NO}_{x}$, as found in Murray et al. (2013). In our multiple linear regression, a regression coefficient that is significantly different from zero at the $95 \%$ confidence level implies that the corresponding process contributes significantly to the variation of simulated ozone. To estimate the variance explained by each predictor, we first calculate the sequential sums of squares over ordering of predictors (see Supplement). The sequential of squares depends on the predictors already in the model; we therefore do the calculation for every possible order in which predictors can enter the model. We then average all the sequential sums of squares to yield an adjusted sum of squares (Kruskal, 1987; Chevan and Sutherland, 1991; Groemping, 2007). This method accounts for the likely possibility that the two predictors are not orthogonal. We use the adjusted sum of squares to quantify the relative contributions of each predictor to the interannual variability of tropospheric ozone. Our study focuses on the austral winter season when the subtropical-jetrelated stratosphere-troposphere exchange reaches the seasonal maximum (Karoly et al., 1998; Bals-Elsholz et al., 2001; Nakamura and Shimpo, 2004). Southern hemispheric biomass burning (e.g., Liu et al., 2010, 2013) also reaches the maximum during this season.

Section 2 briefly describes the model and simulations, including the standard chemistry simulation, the stratospheric $\mathrm{O}_{3}$ tracer simulation, and the tagged $\mathrm{CO}$ simulation. It also describes GEOS-5 ozone assimilation, as the assimilated fields are used to evaluate model performance over the southern hemispheric extra-tropics and tropics as discussed in the first part of Sect. 3. The second part of Sect. 3 presents a diagnostic study of controlling factors, including stratosphere input, surface emissions, and lightning, on the tropospheric ozone IAV relying on a series of hindcast simulations from 1992 to 2011. Section 4 is a summary and conclusion.

\section{Model and data}

\subsection{Model}

We used the Global Modeling Initiative chemical transport model (GMI-CTM) (Duncan et al., 2007; Strahan et al., 2007), driven by MERRA reanalysis meteorology (Rienecker et al., 2011, http://gmao.gsfc.nasa.gov/research/ merra/). The native resolution of the MERRA field is $0.67^{\circ} \times 0.5^{\circ}$ with 72 vertical levels; we regrid it to $2^{\circ} \times 2.5^{\circ}$ horizontal grid for input to the GMI-CTM simulations in this study.

The chemical mechanism used in GMI-CTM represents stratospheric and tropospheric chemistry with offline aerosols input from GOCART model simulations (Chin et al., 2002). The GMI-CTM hindcast simulation has been used and compared to observations in many recent studies. Strahan et al. (2013) showed excellent agreement between simulated and MLS ozone profiles in the Arctic lower stratosphere. Liu et al. (2016) shows the GMI-CTM hindcast and ozonesonde agree very well on the annual cycles and IAV over Réunion from the lower troposphere to the upper troposphere. Strode et al. (2015) shows that the GMI-CTM hindcast reproduces the seasonal cycle and IAV of observed surface ozone over United States from Environmental Protection Agency (EPA)'s Clean Air Status and Trends Network (CASTNET).

The GMI-CTM standard simulation (labeled as HindcastVE) used in this study for 1992-2011 includes monthly and interannually varying emissions with anthropogenic, biomass burning, and biogenic sources. Anthropogenic emissions are based on the EDGAR 3.2 inventory (Olivier et al., 2005), overwritten with available regional inventories for North America, Europe, Asia, and Mexico. More details are given in Strode et al. (2015). Biomass burning emissions are 
from the Global Fire Emission Database, GFED3 (van der Werf et al., 2010). Emissions before 1997 are obtained from GFED3 emission climatology averaged for 2001 to 2009 and applied with regional-scale IAV, which was derived from satellite information on fire activity (ATSR) and/or aerosol optical depths from the TOMS by Duncan et al. (2003). Biogenic emissions of isoprene and monoterpenes follow the latest version of the MEGAN algorithm (Guenther et al., 2006). Besides the standard simulation, we carry out a control run for 1992-2011 by repeating the anthropogenic and biomass emissions for 2000. The comparison between the control and standard simulation removes the possible impact of IAV in meteorology and allows us to quantify effects of emission IAV on ozone IAV.

In our GMI-CTM, the lightning parameterization follows the scheme described by Allen et al. (2010). The regional lightning $\mathrm{NO}_{x}$ emission, calculated online by coupling to the deep convective transport in the model, varies from year to year. The global total of $\mathrm{NO}_{x}$ from lightning is fixed at 5.0 $\mathrm{TgN}_{\text {year }}{ }^{-1}$.

Methane mixing ratios are specified in the two lowest model levels, using time-dependent zonal means from National Oceanic and Atmospheric Administration's Global Monitoring Division (NOAA GMD). Other long-lived source gases important in the stratosphere, such as $\mathrm{N}_{2} \mathrm{O}$, CFCs, and halocarbons, are prescribed at the two lowest model levels following the A2 scenario by WMO (2014). Stratospheric aerosol distributions and trends are from International Global Atmospheric Chemistry/Stratospheric Processes And their Role in Climate (IGAC/SPARC) and have IAV (Eyring et al., 2013).

The model includes a stratospheric $\mathrm{O}_{3}$ tracer $\left(\mathrm{StratO}_{3}\right)$. The $\mathrm{StratO}_{3}$ is defined relative to a dynamically varying tropopause tracer (e90) (Prather et al., 2011). The e90 tracer is set to a uniform mixing ratio $(100 \mathrm{ppb})$ at the surface with 90 days e-folding lifetime. In our simulation, the e 90 tropopause value is $75 \mathrm{ppb}$. The $\mathrm{StratO}_{3}$ tracer is set equal to $\mathrm{O}_{3}$ in the stratosphere and is removed in the troposphere with the same loss frequency (chemistry and deposition) archived from daily output of the standard chemistry model simulation with yearly-varied emission in this study. Using the $\mathrm{StratO}_{3}$ tracer allows quantification of $\mathrm{O}_{3}$ of stratospheric origin in the troposphere at a given location and time. This approach has also been adopted in the high-resolution GFDL AM3 model (Lin et al., 2012).

In this study, we also conducted a tagged $\mathrm{CO}$ simulation to examine the emission sources during the same period as the full chemistry simulation. The tagged $\mathrm{CO}$ simulation has horizontal resolution of $1^{\circ} \times 1.25^{\circ}$. The primary chemical loss of $\mathrm{CO}$ is through reactions with $\mathrm{OH}$ radicals, which are archived from the respective standard chemistry simulation with yearly-varied emissions. The chemical production and loss rates of $\mathrm{CO}$ in the stratosphere were archived from the respective standard chemistry simulations.

\subsection{GMAO GEOS-5 Ozone Assimilation}

We used assimilated tropospheric ozone to evaluate model performance. This assimilated dataset is produced by ingesting OMI v8.5 total column ozone and MLS v3.3 ozone profiles into a version of the Goddard Earth Observing System, Version 5 (GEOS-5) data assimilation system (Rienecker et al., 2011). No ozonesonde data are used in the assimilation. Wargan et al. (2015) provides details of the GEOS5.7.2 assimilation system, which for this application is produced with $2^{\circ} \times 2.5^{\circ}$ horizontal resolution and with 72 vertical layers between the surface and $0.01 \mathrm{hPa}$. For the troposphere, the assimilation only applies a dry deposition mechanism at the surface without any chemical production or loss. This algorithm works since the ozone lifetime is much longer than the $6 \mathrm{~h}$ analysis time on which the background field is corrected by observations. Ziemke et al. (2014) evaluated the tropospheric ozone profiles derived from three strategies based on OMI and MLS measurements, including this GEOS-5 assimilation, trajectory mapping, and direct profile retrieval using a residual method, with ozonesonde observations and GMI model simulations. They show that the ozone product ( $500 \mathrm{hPa}$ to tropopause) from the GEOS-5 assimilation is the most realistic. Wargan et al. (2015) also demonstrate that the ozone between $500 \mathrm{hPa}$ and the tropopause from GEOS-5 assimilation is in good agreement with independent observations from ozonesondes. The assimilation applies the OMI averaging kernels in the troposphere, but the weight of OMI kernels decreases sharply below $500 \mathrm{hPa}$ (K. Wargan, personal communication, 2016). Considering that in the lower troposphere there is no direct observational constraint in the analysis, we use ozone mixing ratio at 270 and $430 \mathrm{hPa}$ as well as partial column ozone integrated from $500 \mathrm{hPa}$ to the tropopause from GEOS-5 assimilation as a reference value to evaluate our GMI model simulation. To compare the GEOS-5 assimilated tropospheric partial column above $500 \mathrm{hPa}$ with GMI-CTM ozone simulation, we use the same tropopause as defined by the lower of the 3.5 potential vorticity units (PVUs) isosurface and the $380 \mathrm{~K}$ isentropic surface.

\section{Results}

\subsection{Temporal and spatial distribution of SHTOM in GMI-CTM and GMAO GEOS-5 assimilated ozone product}

Figure 1 shows the spatial pattern of southern hemispheric partial column ozone (from $500 \mathrm{hPa}$ to the tropopause) in four seasons averaged over 2005 to 2011 from the GMAO GEOS-5 assimilated dataset and the GMI-CTM hindcast simulations. To account for a low bias in the GEOS-5 ozone product (Wargan et al., 2015), we added 2.5 DU to the assimilated column in the tropics $\left(0-30^{\circ} \mathrm{S}\right)$. The GMI-CTM sim- 

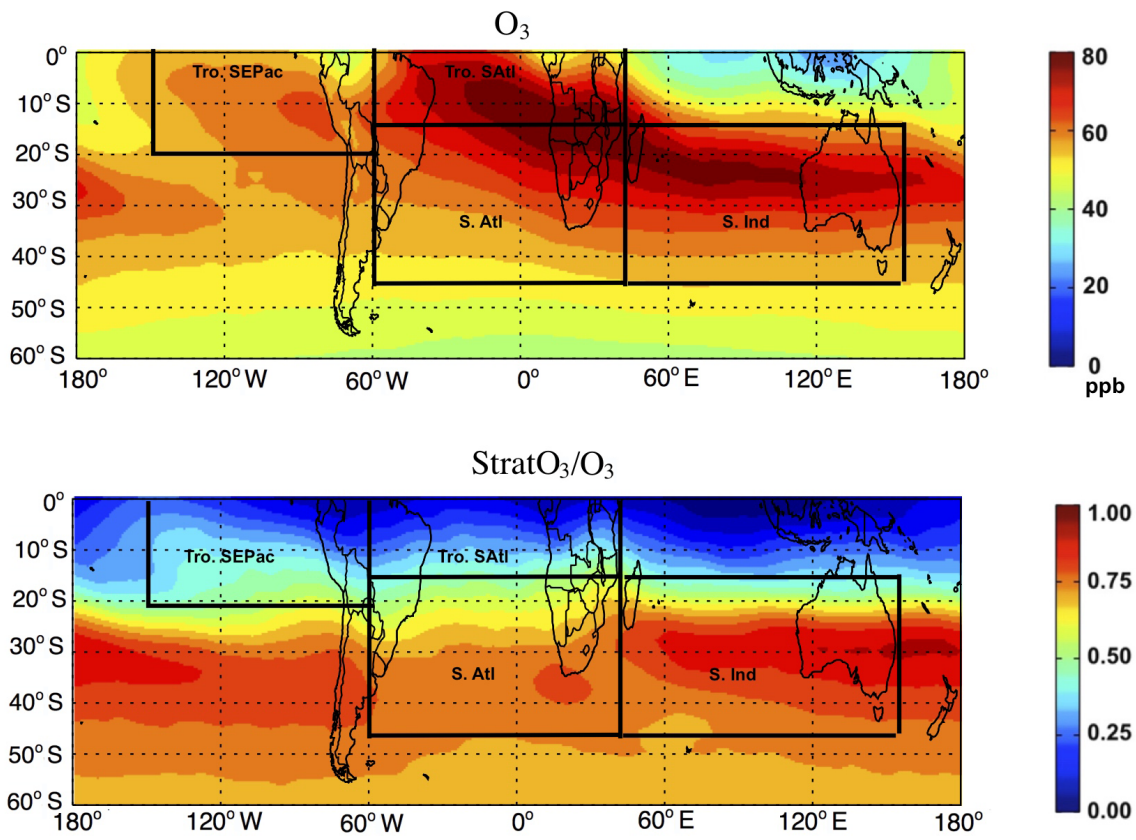

Figure 2. The simulated ozone (top) and the $\mathrm{StratO}_{3} / \mathrm{O}_{3}$ (bottom) at $430 \mathrm{hPa}$ averaged over 1992-2011 in September. Stronger stratospheric influence happens over the Southern Hemisphere centered on $30^{\circ} \mathrm{S}$, co-locating with subtropical jet-stream regions with descending stratospheric air. The black boxes show the four regions discussed in this study. From left to right: (1) tropical southeastern Pacific $\left(0-20^{\circ} \mathrm{S}\right.$, $\left.150-60^{\circ} \mathrm{W}\right)$; (2) tropical South Atlantic region $\left(0-15^{\circ} \mathrm{S}, 60^{\circ} \mathrm{W}-40^{\circ} \mathrm{E}\right)$; (3) subtropical South Atlantic region $\left(15-45^{\circ} \mathrm{S}, 60^{\circ} \mathrm{W}-40^{\circ} \mathrm{E}\right)$; and (4) subtropical South Indian Ocean $\left(15-45^{\circ} \mathrm{S}, 40-150^{\circ} \mathrm{E}\right)$.

ulation reproduces the seasonality and spatial distribution of southern hemispheric ozone maximum as shown in GEOS5 assimilated product with (a) the elevated ozone centered over the Atlantic Ocean from the Equator to $40^{\circ} \mathrm{S}$, (b) the ozone maximum extending southeastward to southern Africa and the Indian Ocean in the latitude band of $30-45^{\circ} \mathrm{S}$, and (c) the relatively weaker enhancement extending westward to South America and the tropical southeastern Pacific. The ozone maximum is strongest in austral winter-spring and weakest in austral fall. Both GMI-CTM and GEOS-5 assimilation show the very low tropospheric ozone over the western Pacific and the tropical eastern Indian Ocean, where the ozone-poor marine boundary layer air is lifted into the upper troposphere (Folkins et al., 2002; Solomon et al., 2005).

\subsection{Sub-regions of SHTOM}

The tropospheric ozone distribution in any region depends on the advection and mixing, its proximity to the polluted area, and descent of ozone-rich air from the stratosphere. We show in Fig. 2 the maps of simulated $\mathrm{O}_{3}$ and $\mathrm{StratO}_{3} / \mathrm{O}_{3}$ at $430 \mathrm{hPa}$ averaged over 1992 to 2011 in September, when the southern hemispheric biomass burning peaks. The $\mathrm{StratO}_{3} / \mathrm{O}_{3}$ ratio represents the fraction of tropospheric ozone from the stratosphere and is used to identify the regions with distinct stratospheric input. Differences in the spatial patterns of the maximum or minimum in ozone mixing ratio and $\mathrm{StratO}_{3} / \mathrm{O}_{3}$ ratio identifies regions where ozone is affected by factors other than the stratospheric input.

The region with minimum stratospheric ozone contribution occurs along the Equator. In the tropics, the southward extension of regions with minimum stratospheric ozone contribution shows zonal variation, reaching 5 to $10^{\circ} \mathrm{S}$ over tropical eastern Pacific and tropical Atlantic, and further south to approximately $15^{\circ} \mathrm{S}$ over the Indian Ocean and the Maritime Continents, which is closely related to the Walker Circulation. In this tropical zonal circulation, air rises over the Maritime Continents (together with deep convection) and descends over the eastern Pacific (Bjerknes, 1969). Similar zonal circulation is found over the Atlantic with rising due to radiative heating over tropical Africa and South America and sinking due to radiative cooling over the tropical Atlantic (Julian and Chervin, 1978). The longitudinal variation of ozone at $430 \mathrm{hPa}$ in the tropics is in agreement with the changes of $\mathrm{StratO}_{3} / \mathrm{O}_{3}$, showing ozone minimum over Maritime Continents as well as elevated ozone over the eastern Pacific and Atlantic. Within the Atlantic, despite the smaller stratospheric contribution, the tropics have higher ozone mixing ratio (> $80 \mathrm{ppb}$ ) than the subtropics at $430 \mathrm{hPa}$, and other sources must also contribute to the ozone maximum over the tropical South Atlantic. Ozone over the tropical southeastern Pacific is also slightly elevated. The maximum stratospheric influence is found over the southern Indian and Pacific oceans centered on $30^{\circ} \mathrm{S}$, co-located with the tropo- 

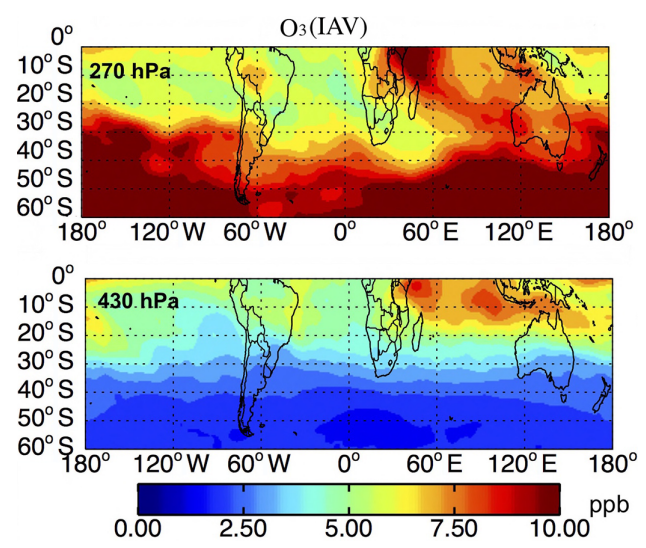

Figure 3. The interannual variations (IAV, unit of ppb) of simulated ozone at $270 \mathrm{hPa}$ (top) and $430 \mathrm{hPa}$ (bottom). The standard deviation of ozone anomalies (removing the monthly mean) over 1992-2011 represents the IAV.

spheric $\mathrm{O}_{3}$ maximum over these regions. Both ozone and $\mathrm{StratO}_{3} / \mathrm{O}_{3}$ over the subtropics show strong longitudinal variations, with the co-located maxima over the South Indian Ocean. The ozone minimum at $430 \mathrm{hPa}$ at $30^{\circ} \mathrm{S}$ occurs over the eastern Pacific region, while the minimum contribution of the stratospheric input is over the South Atlantic region. Given the spatial variations of the maximum or minimum in $\mathrm{StratO}_{3} / \mathrm{O}_{3}$ ratio and ozone mixing ratio, we separate the southern hemispheric ozone maximum into four sub-regions: (1) tropical southeastern Pacific $\left(0-20^{\circ} \mathrm{S}, 150\right.$ $\left.60^{\circ} \mathrm{W}\right)$; (2) tropical South Atlantic $\left(0-15^{\circ} \mathrm{S}, 60^{\circ} \mathrm{W}-40^{\circ} \mathrm{E}\right)$; (3) subtropical South Atlantic $\left(15-45^{\circ} \mathrm{S}, 60^{\circ} \mathrm{W}-40^{\circ} \mathrm{E}\right)$; and (4) subtropical South Indian Ocean $\left(15-45^{\circ} \mathrm{S}, 40-150^{\circ} \mathrm{E}\right)$. We show in Fig. 3 the maps of the IAV of simulated $\mathrm{O}_{3}$ at 270 and $430 \mathrm{hPa}$. The IAV is represented by the standard deviation of ozone anomalies (removing the monthly mean averaged from 1992 to 2011) over 1992-2011. Relatively stronger ozone IAV happens over subtropical South Atlantic and subtropical South Indian Ocean at $270 \mathrm{hPa}$. At $430 \mathrm{hPa}$, tropical southeastern Pacific and tropical South Atlantic has slightly larger IAV. In this paper, we examine and quantify the relative roles of dynamics and chemistry on the IAV of tropospheric ozone variations over these selected regions during the past 20 years.

Figure 4 compares the anomalies of modeled and assimilated upper tropospheric ozone columns (UTOC, integrated from $500 \mathrm{hPa}$ to the tropopause) as well as the anomalies of corresponding tropospheric ozone mixing ratio at 270 and $430 \mathrm{hPa}$ over two tropical sub-regions (tropical South Atlantic and tropical southeastern Pacific) from 2005 to 2011. The anomalies are calculated by removing the monthly mean averaged from 2005 to 2011. The short timescale variations in the model simulation tend to be greater compared to that in the assimilated ozone products, especially over the tropical South Atlantic region. But in general, the GMI-CTM hind- cast simulation captures the assimilated IAV of the tropospheric ozone at these two levels as well as for the UTOC. Over the tropical South Atlantic, the modeled IAV agrees with the phase changes of assimilated ozone IAV, but the simulation overestimates the assimilated ozone maximum in 2010 and underestimates the assimilated minima in 2007 and 2011 at both levels. Over the tropical southeastern Pacific, the IAV is influenced by ENSO-related changes in dynamics (e.g., Ziemke et al., 2010; Oman et al., 2011, 2013). The simulation reproduces much of the assimilated IAV, showing high ozone anomalies after 2005 and 2010 La Niña years and negative ozone anomalies after a strong El Niño year in 2009. However, during October 2006 to January 2007, the simulation shows a pronounced ozone peak, especially at $270 \mathrm{hPa}$, which is not seen in the assimilated ozone. Logan et al. (2008) examined interannual variations of tropospheric ozone profiles in October-December between 2005 and 2006 based on the satellite observations from Tropospheric Emission Spectrometer (TES). The TES data agree with what we found in the GMI-CTM model simulation, showing ozone enhancement over the tropical southeastern Pacific $\left(150-60^{\circ} \mathrm{W}, 0-12^{\circ} \mathrm{S}\right)$ region in November 2006 relative to $2005(\sim 5-10 \mathrm{ppb}$ at $250 \mathrm{hPa}$ and $0-5 \mathrm{ppb}$ at $400 \mathrm{hPa}$, Fig. 3 of Logan et al., 2008). The agreement between TES and GMI-CTM indicates a possible low bias of GMAO assimilated ozone during late 2006, as a result of the low sensitivity of OMI (Wargan et al., 2015).

Figure 5 shows a similar comparison to Fig. 4 , but over the two subtropical regions. Over the South Atlantic region, the assimilated ozone has similar but stronger IAV than that over the tropical southeastern Pacific region, showing the largest ozone year-by-year variation $(\sim 20 \mathrm{ppb}$ at $270 \mathrm{hPa})$ from October 2009 to October 2010, and the GMI-CTM simulation reproduces this variation quite well. Over the South Indian Ocean region, our model reproduces most of the variations in magnitude and phase, but shows anti-phase variations in late 2006-early 2007, which substantially affected the calculated correlation coefficients between model and assimilated ozone. The simulated upper tropospheric ozone column reproduces the IAV in the assimilated ozone column well, except for late 2006. In general, agreement between the simulated and assimilated results confirms the suitability of the model for investigations of the controlling factors on the tropospheric ozone IAV over these regions.

The left column of Fig. 6 presents the monthly profiles of correlation coefficients between the simulated ozone and $\mathrm{StratO}_{3}$ over the four sub-regions. Strong positive correlations between $\mathrm{StratO}_{3}$ and $\mathrm{O}_{3}$ are observed in most seasons in the upper troposphere, even over two tropical regions. Stratospheric influence plays a big role during austral winter-spring and reaches its seasonal maximum in August, when the subtropical jet system is strongest and moves to its northernmost location. Over the two subtropical regions, the strong stratospheric influence persists throughout the whole troposphere $(r>0.8$ at $700 \mathrm{hPa})$ in August. Over the tropical 

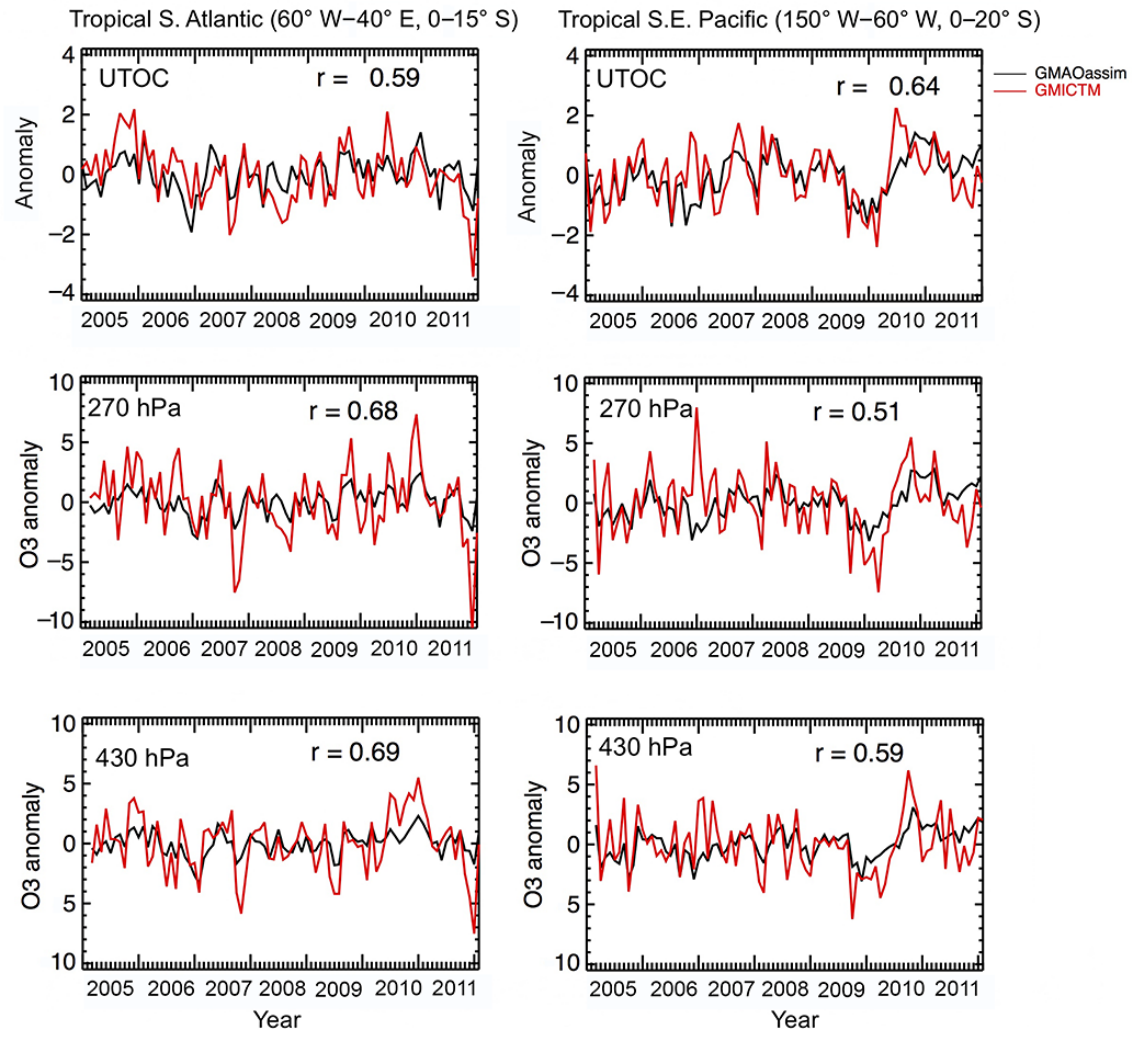

Figure 4. Time series plots of upper tropospheric ozone column (UTOC, integrated from $500 \mathrm{hPa}$ to the tropopause; unit: DU) anomalies and tropospheric ozone anomalies (unit: ppb) at 270 and $430 \mathrm{hPa}$ from GMAO assimilated data (black) and GMI-CTM (red) over (left) the tropical South Atlantic region $\left(60^{\circ} \mathrm{W}-40^{\circ} \mathrm{E}, 0-15^{\circ} \mathrm{S}\right)$ and (right) tropical southeastern Pacific $\left(150-60^{\circ} \mathrm{W}, 0-20^{\circ} \mathrm{S}\right)$ from 2005 to 2011. The anomalies are calculated by removing the monthly mean averaged from 2005 to 2011.

South Atlantic region, the strong stratospheric influence is limited to the upper troposphere in austral winter-spring and decreases sharply with decreasing altitude. Over the tropical southeastern Pacific, the strong stratospheric influence persists year-long at the upper troposphere and reaches as low as $\sim 400 \mathrm{hPa}$ except for December.

The right column of Fig. 6 shows the seasonal profiles of correlation coefficients between ozone and ozone from emissions $\left(\mathrm{EmissO}_{3}\right)$. The $\mathrm{EmissO}_{3}$ is the difference between the simulations with varied and constant emission. Over the two subtropical regions, there are two seasonal maxima in the correlations between ozone and $\mathrm{EmissO}_{3}$. The first occurs in September at the lower troposphere and decreases with increasing altitude, the second is in December-January showing an opposite vertical gradient with stronger correlations in the upper and middle troposphere. Over the tropical southeastern Pacific region, the influence from emissions shows a similar double-peak pattern, but with the first maximum localized at the surface and the second peak localized in the upper troposphere. Over the tropical South Atlantic, the influence of emissions is very small. South America and southern Africa are two major nearby burning regions. Emissions over South America have much larger IAV than those over south- ern Africa, although African emissions are larger in absolute terms (Sauvage et al., 2007; Liu et al., 2010; Voulgarakis et al., 2015). Sauvage et al. (2007) argued that emissions over South and Southeast Asia could be transported southward in the upper troposphere through the tropical easterly jet and affect ozone over Africa, the Atlantic, and the Indian Ocean (Hoskins and Rodwell, 1995; Rodwell and Hoskins, 2001). Meanwhile, emissions over this region also show large IAV (Voulgarakis et al., 2015). Therefore, the interannual emission changes in South America $\left(0-20^{\circ} \mathrm{S}, 72.5-37.5^{\circ} \mathrm{W}\right)$, southern Africa $\left(5-20^{\circ} \mathrm{S}, 12-38^{\circ} \mathrm{E}\right)$, and South and Southeast Asia $\left(70-125^{\circ} \mathrm{E}, 10^{\circ} \mathrm{S}-40^{\circ} \mathrm{N}\right)$ may all affect the IAV of ozone due to emission changes in the Southern Hemisphere. In this study, we rely on tagged CO simulation to quantify the influence of biomass burning emissions from these three burning regions during months when emission IAV contributes significantly to the IAV of ozone.

In the next section, we choose August (the seasonal maximum of stratospheric input into the lower troposphere), September, and December (the seasonal maximum of emission contribution) as three example months to examine the relative roles of different factors on IAV of tropospheric ozone over these regions. 

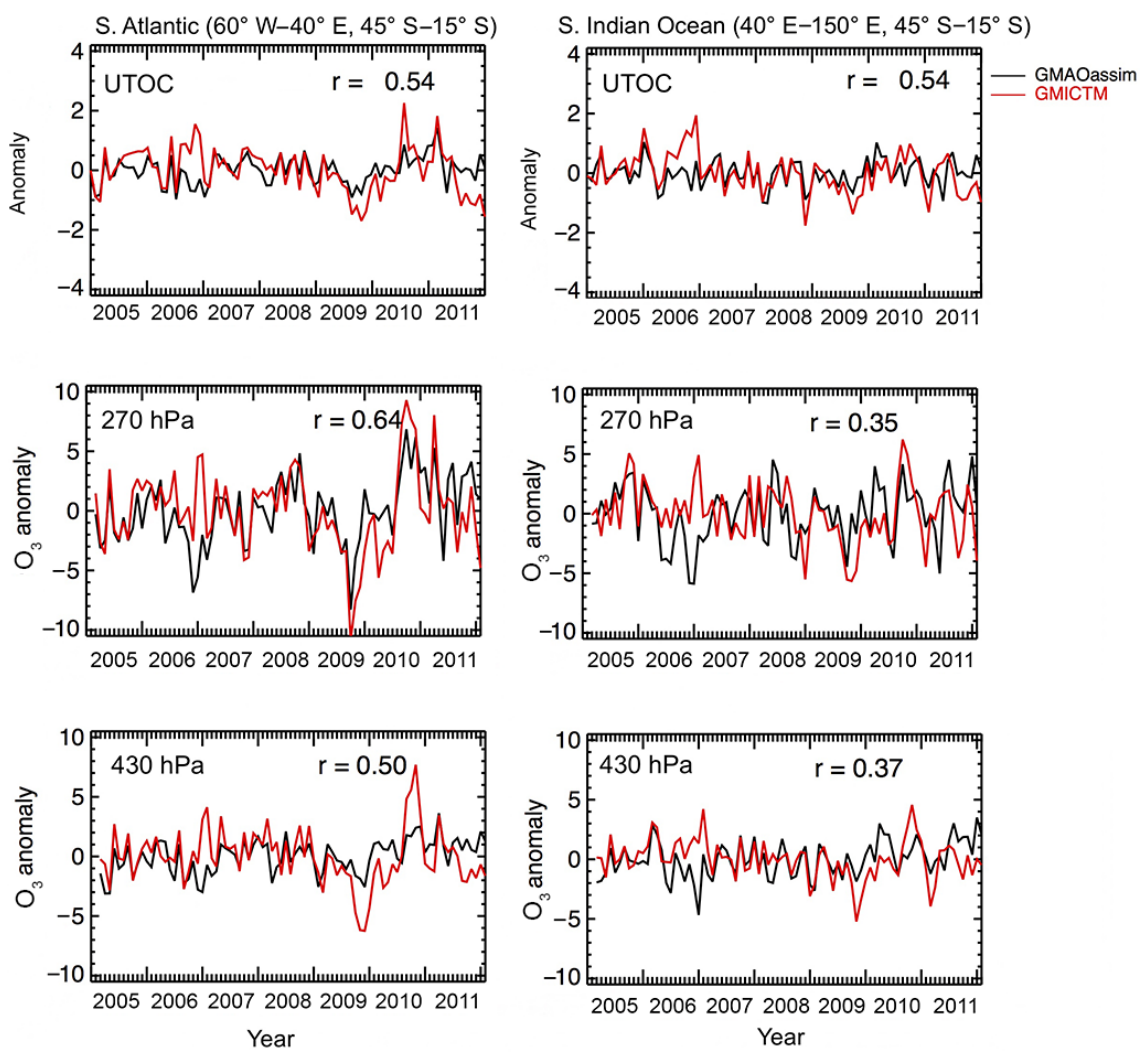

Figure 5. Time series plots of upper tropospheric ozone column (UTOC, integrated from $500 \mathrm{hPa}$ to the tropopause; unit: DU) anomalies and tropospheric ozone anomalies (unit: ppb) at 270 and $430 \mathrm{hPa}$ from GMAO assimilated data (black) and GMI-CTM (red) over (left) the South Atlantic $\left(60^{\circ} \mathrm{W}-40^{\circ} \mathrm{E}, 15-45^{\circ} \mathrm{S}\right)$ and (right) South Indian Ocean $\left(40-150^{\circ} \mathrm{E}, 15-45^{\circ} \mathrm{S}\right)$ from 2005 to 2011 . The anomalies are calculated by removing the monthly mean averaged from 2005 to 2011 .

\subsection{Factors controlling IAV in ozone in the middle and upper troposphere}

\subsubsection{South Atlantic region}

Figure 7 shows the multiple regression results over the South Atlantic region. It compares the simulated ozone anomalies to those calculated from two regression variables: $\mathrm{StratO}_{3}$ and $\mathrm{EmissO}_{3}$ at 270 and $430 \mathrm{hPa}$ in August, September, and December. The fitted ozone anomalies generally reproduce the IAV obtained from the GMI-CTM simulation. The explained proportion of variability in simulated ozone anomalies by $\mathrm{StratO}_{3}$ and $\mathrm{EmissO}_{3}$ is mostly above $50 \%$ and reaches as high as $\sim 76 \%$ in December at $270 \mathrm{hPa}$, which demonstrates that $\mathrm{StratO}_{3}$ and $\mathrm{EmissO}_{3}$ are sufficient to explain the IAV of tropospheric ozone over the South Atlantic region. In August at $430 \mathrm{hPa}$, the fitted ozone anomalies have a slightly weaker correlation with the simulated ozone and show less IAV compared to the ozone anomalies in GMICTM.

Figure 8 exhibits regression results in a way that highlights the relative contributions of the IAV of stratospheric input and emission on the IAV of ozone over the South Atlantic.
The three panels represent results from August, September, and December from 1992 to 2011. Each panel has two columns, which illustrate the respective contribution from changes in $\mathrm{StratO}_{3}$ and $\mathrm{EmissO}_{3}$ on the IAV of ozone mixing ratio. The left column of each panel compares the anomalies of $\mathrm{StratO}_{3}$ (blue) and simulated ozone mixing ratio (black) from the GMI-CTM model at 270 and $430 \mathrm{hPa}$. The right column compares the simulated $\mathrm{O}_{3}$ residual after removing the regression from $\mathrm{StratO}_{3}$ (black line) and $\mathrm{EmissO}_{3}$ (green line) at these two levels. The regression coefficient $(\beta)$ and its $95 \%$ confidence level are labeled in each panel and help us to determine whether the corresponding contribution is significant to explain the variation of simulated ozone. As discussed before, $\mathrm{Emiss}_{3}$ reflects the effects from surface emission changes on ozone variations at interannual timescales. The stratospheric input reaches its seasonal maximum in $\mathrm{Au}-$ gust, during which the stratospheric contribution is significant throughout the troposphere, explaining about $66 \%$ of the simulated ozone variance at $270 \mathrm{hPa}$ and $37 \%$ at $430 \mathrm{hPa}$. The contributions from emission changes are very small and insignificant at these two levels in August. In September, the IAV of stratospheric input explains about $55 \%$ of the IAV in ozone at $270 \mathrm{hPa}$. The contribution decreases but is still sig- 
Correlation of $\mathrm{StratO}_{3}$ and $\mathrm{O}_{3}$ (1992-2011) Correlation of $\mathrm{EmissO}_{3}$ and $\mathrm{O}_{3}$ (1992-2011)

(a) S. Atlantic $\left(60^{\circ} \mathrm{W}-40^{\circ} \mathrm{E}, 45^{\circ} \mathrm{S}-15^{\circ} \mathrm{S}\right)$
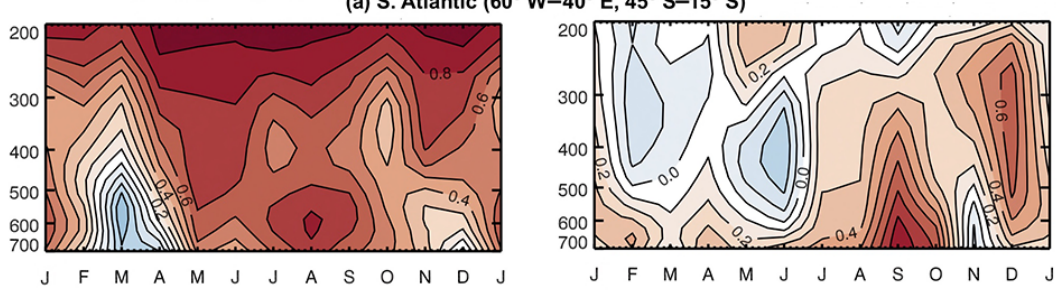

(b) S. Indian Ocean $\left(40^{\circ} \mathrm{E}-150^{\circ} \mathrm{E}, 45^{\circ} \mathrm{S}-15^{\circ} \mathrm{S}\right)$

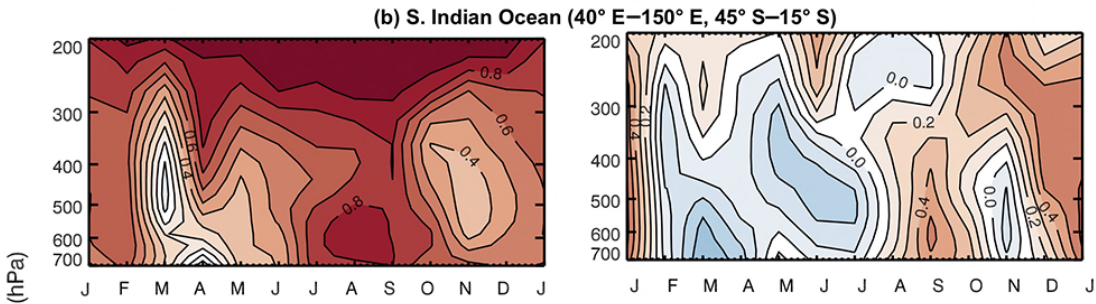

(c) Tropical S. Atlantic $\left(60^{\circ} \mathrm{W}-40^{\circ} \mathrm{E}, 0-15^{\circ} \mathrm{S}\right)$
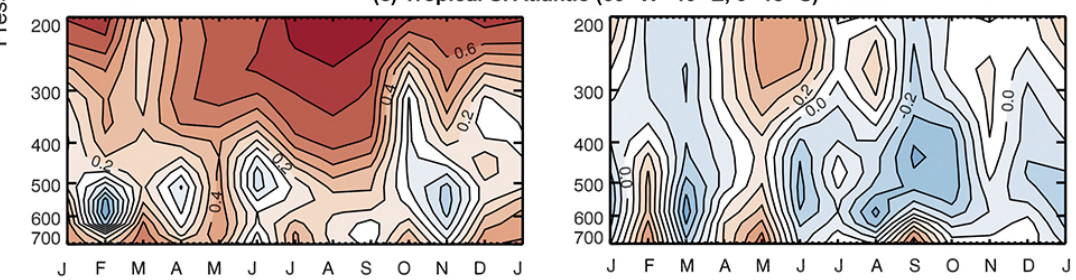

(d) Tropical S. E. Pacific $\left(150^{\circ} \mathrm{W}-60^{\circ} \mathrm{W}, 0-20^{\circ} \mathrm{S}\right)$
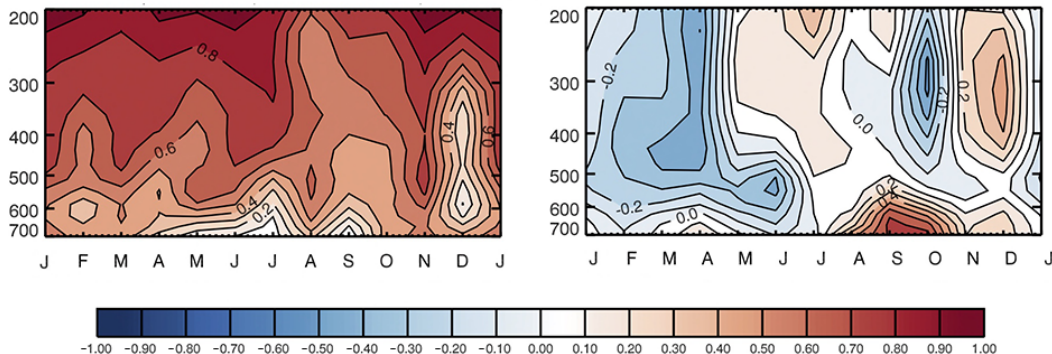

Figure 6. Monthly profile maps of correlation coefficients between ozone and (left) $\mathrm{StratO}_{3}$ and (right) $\mathrm{EmissO}_{3}$ from 1992 to 2011 over the (a) South Atlantic $\left(60^{\circ} \mathrm{W}-40^{\circ} \mathrm{E}, 15-45^{\circ} \mathrm{S}\right)$; (b) South Indian Ocean $\left(40-150^{\circ} \mathrm{E}, 15-45^{\circ} \mathrm{S}\right)$; (c) tropical South Atlantic region $\left(60^{\circ} \mathrm{W}-40^{\circ} \mathrm{E}\right.$, $\left.0-15^{\circ} \mathrm{S}\right)$; and (d) tropical southeastern Pacific $\left(150-60^{\circ} \mathrm{W}, 0-20^{\circ} \mathrm{S}\right)$. The $y$ axis is pressure in pascal units $(\mathrm{hPa})$.

nificant at $430 \mathrm{hPa}$. The IAV of surface emissions contributes substantially to the IAV of ozone in September. The influence of emissions exceeds that of the stratosphere and explains about $35 \%$ of IAV in ozone at $430 \mathrm{hPa}$. In December, the contribution from stratospheric input to the IAV of ozone is dominant $(\sim 47 \%)$ at $270 \mathrm{hPa}$. The contribution from emission is also significant at this level and explains the $28 \%$ variance of IAV of ozone. At $430 \mathrm{hPa}$, the contribution from emission exceeds that from stratospheric input.

We quantify emission contributions from three burning regions using a tagged $\mathrm{CO}$ simulation. Figure 9 shows standardized anomalies of the tagged CO tracers over the South Atlantic from three burning source regions, including southern Africa (red), South America (blue), and South and South- east Asia (green) and their comparison with the $\mathrm{Emiss}_{3}$ at 270 and $430 \mathrm{hPa}$ in September and December from 1992 to 2011. The direct downwind transport of emissions from South America contributes most to the ozone variability from emissions over this region in September at both levels, and the effects are most significant in the lower level $(\sim 58 \%$ at $430 \mathrm{hPa}$ ). In the upper troposphere, besides the contribution from South America, the uplift and cross-Equator transport of pollutants from South and Southeast Asia also contributes $(>10 \%)$ to the ozone variation over the South Atlantic region. The contribution from southern Africa is small and less than $10 \%$ at both levels. We also note that both $\mathrm{StratO}_{3}$ and $\mathrm{EmissO}_{3}$ show a minimum in 2009 and a maximum in 2010. There was a strong El Niño event in 2009- 
S. Atlantic $\left(60^{\circ} \mathrm{W}-40^{\circ} \mathrm{E}, 45^{\circ} \mathrm{S}-15^{\circ} \mathrm{S}\right)$

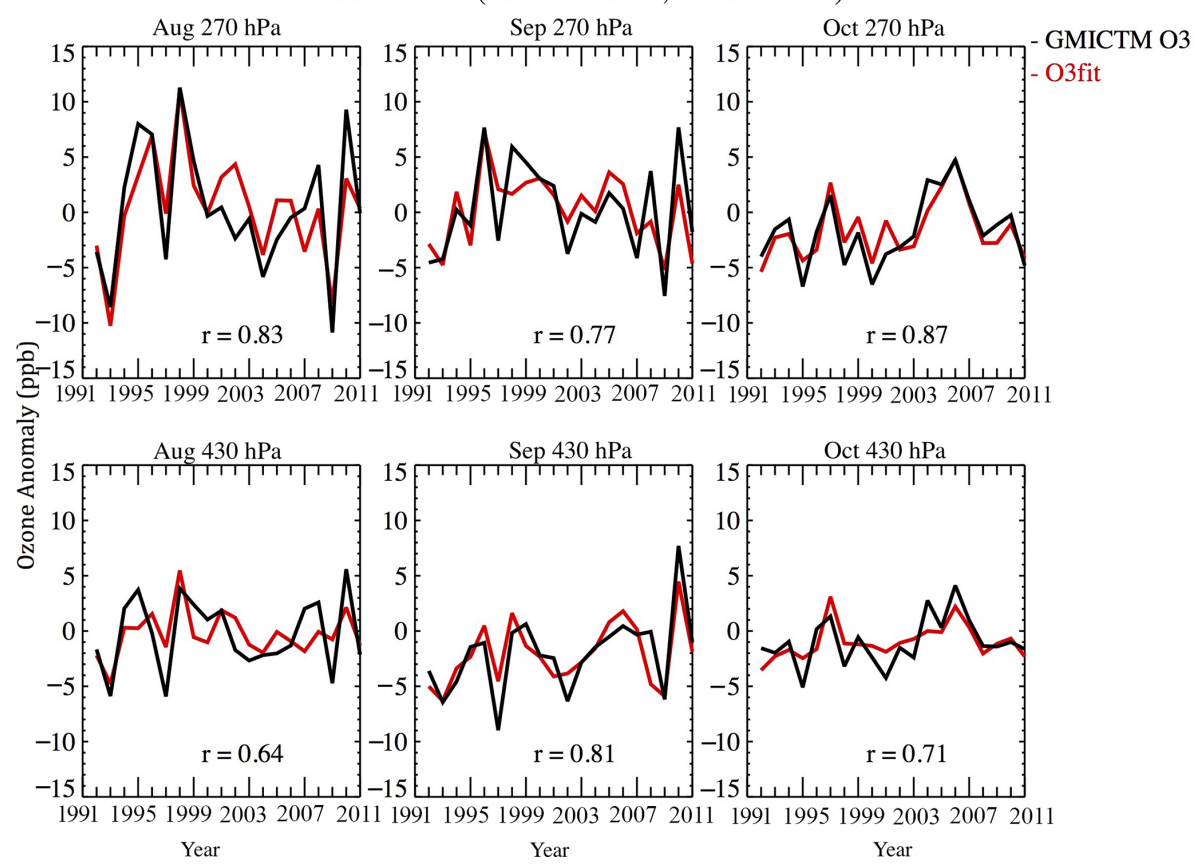

Figure 7. Comparison of the simulated ozone anomalies and the calculated ozone anomalies relying on two predictor variables: $\mathrm{StratO}_{3}$ and $\mathrm{EmissO}_{3}$ at 270 and $430 \mathrm{hPa}$ over the South Atlantic region. Three panels show results from August (left), September (middle), and December (right) from 1992 to 2011. Unit for $y$ axis is parts per billion (ppb).

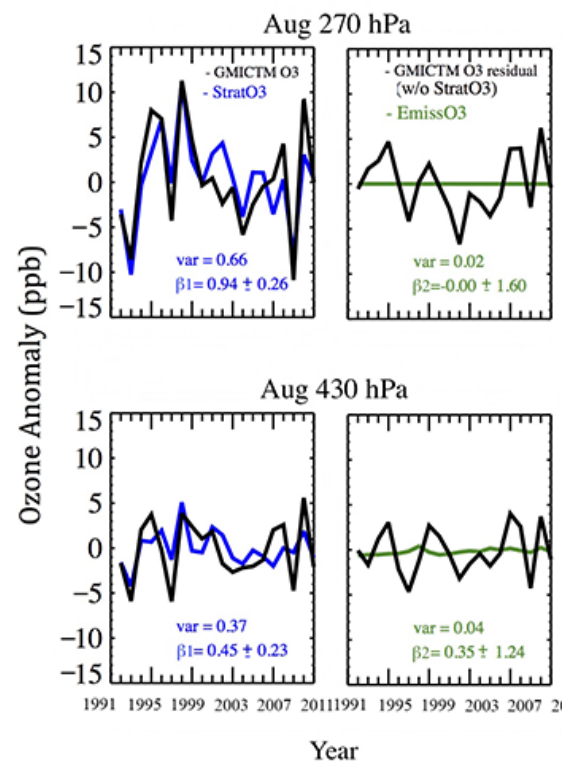

S. Atlantic $\left(60^{\circ} \mathrm{W}-40^{\circ} \mathrm{E}, 45^{\circ} \mathrm{S}-15^{\circ} \mathrm{S}\right)$
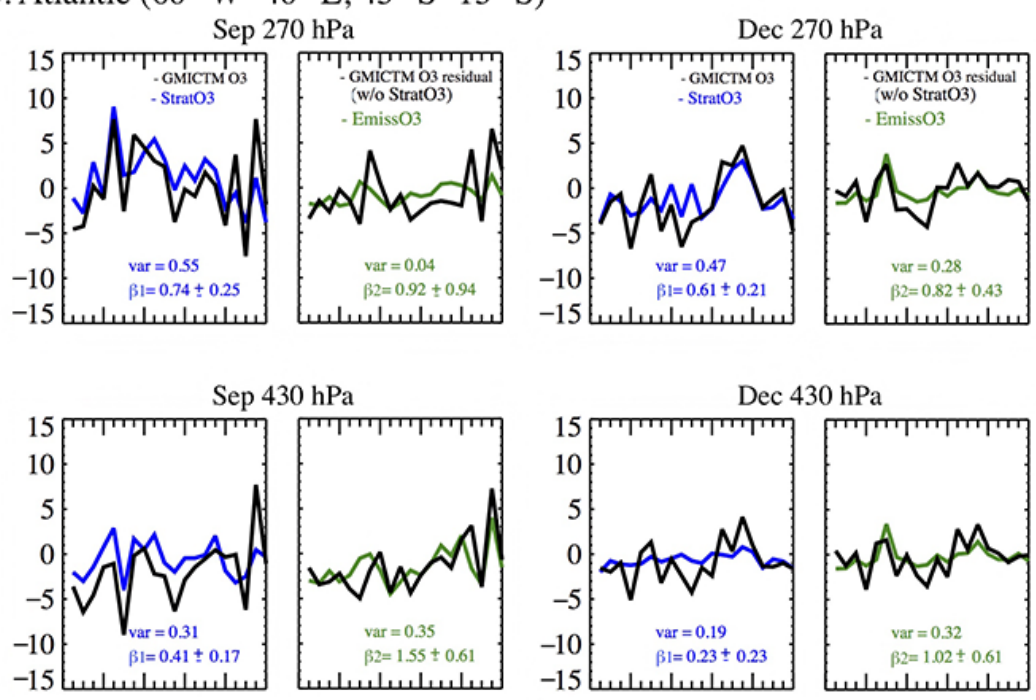

$$
\text { Year }
$$

Year

Year

Figure 8. The multi-regression results of simulated ozone anomalies over the South Atlantic region relying on two predictor variables: $\mathrm{StratO}_{3}$ (blue) and $\mathrm{EmissO}_{3}$ (green) at 270 and $430 \mathrm{hPa}$. Three panels show results from August (left), September (middle), and December (right) from 1992 to 2011. Each panel contains two columns. The left column of each panel compares the anomalies of StratO 3 (blue) and simulated ozone mixing ratio (black) from the GMI-CTM model at 270 and $430 \mathrm{hPa}$. The right column compares the simulated $\mathrm{O}_{3}$ residual after removing the regression from $\mathrm{StratO}_{3}$ (black line) and $\mathrm{EmissO}_{3}$ (green line) at these two levels. EmissO $\mathrm{E}_{3}$ is calculated from the difference of simulated ozone between the run with yearly-varied emission and the run with constant emission. Unit for $y$ axis is parts per billion ( $\mathrm{ppb}$ ). The variance explained by each predictor (var), regression coefficient $(\beta)$, and its $95 \%$ confidence level are labeled in each panel. 

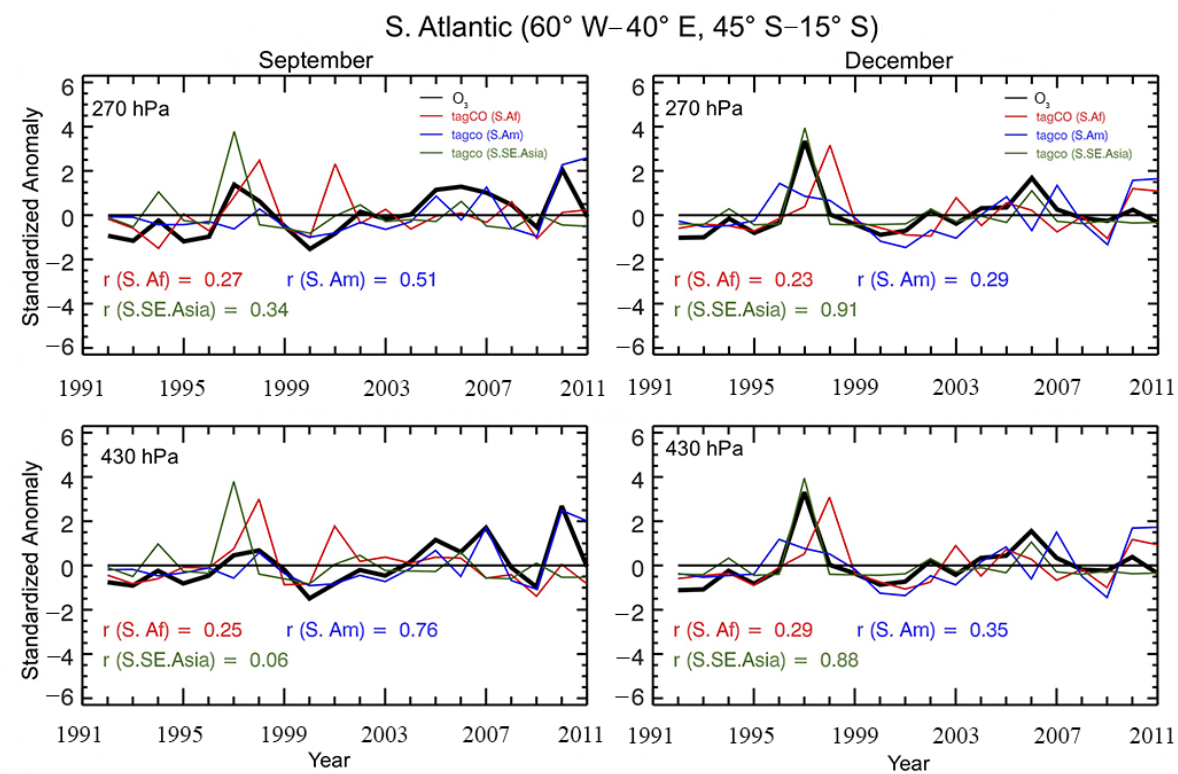

Figure 9. The standardized anomalies of the tagged $\mathrm{CO}$ tracers over the South Atlantic from three burning source regions, including southern Africa (red), South America (blue), and South and Southeast Asia (green), and their comparison with the EmissO 3 (black) at 270 and 430 hPa in September and December from 1992 to 2011.

2010. Neu et al. (2014) identified the increased stratospheric circulation in 2010 driven by El Niño-easterly QBO based on TES data. A few other studies (e.g., Chen et al., 2011; Lewis et al., 2011) found that combined effects of the 20092010 El Niño and warmer-than-normal Atlantic SST produced a severe drought over South America and caused extensive biomass burning emission in the 2010 dry season. Therefore, the agreements between changes in the $\mathrm{StratO}_{3}$ and $\mathrm{EmissO}_{3}$ over 2009-2010 are at least partly driven by ENSO. Similar tropospheric ozone anomalies are observed after the 1997 and 2006 El Niño events. Olsen et al. (2016) examined the magnitude and spatial distribution of ENSO effects on tropospheric column ozone using the assimilated fields and found a statistically significant negative response of tropospheric column ozone to the Niño 3.4 index over South Atlantic Ocean.

In December, emissions from South America and southern Africa do not contribute substantially to the IAV of $\mathrm{EmissO}_{3}$. Emissions from South and Southeast Asia dominate, explaining 83 and $77 \%$ variance of $\mathrm{EmissO}_{3}$ IAV at 270 and $430 \mathrm{hPa}$. The pollutants from South and Southeast Asia have the stronger influence at the upper troposphere because of their transport pathway as discussed in Sauvage et al. (2007). Therefore, the emission contribution of tropospheric ozone IAV becomes significant at $270 \mathrm{hPa}$ in December.

In summary, over the South Atlantic region, the stratospheric input plays a dominant role in the upper troposphere, with a seasonal maximum in August. At $430 \mathrm{hPa}$ the contribution from emission changes to the IAV of ozone exceeds that of stratospheric input in September and Decem- ber. A tagged CO simulation from 1992 to 2011 shows the direct downwind transport of pollutants from South America is the largest contributor to $\mathrm{EmissO}_{3}$ in September, and it is strongest near the surface. In December, cross-Equator transport of South and Southeast Asia pollutants is the most important source of IAV due to emissions, and the effects are stronger in the upper troposphere.

\subsubsection{South Indian Ocean}

Over the South Indian Ocean, the fitted and simulated ozone anomalies are in excellent agreement (Fig. 10). The explained proportion of variability in simulated ozone anomalies by $\mathrm{StratO}_{3}$ and $\mathrm{EmissO}_{3}$ is as high as $\sim 88 \%$ in August at $270 \mathrm{hPa}$. We show relative contribution to the IAV in ozone due to stratospheric input and emission as obtained from multiple linear regression in Fig. 11. In August and September, stratospheric input contributes more than $85 \%$ to ozone IAV at $270 \mathrm{hPa}$. The stratospheric contribution decreases slightly but is still dominant and significant at $430 \mathrm{hPa}(\sim 49 \%$ in August and $60 \%$ in September). The emission contribution, which is mainly from downwind transport of pollutants from South America and southern Africa (Fig. 12), is most important at $430 \mathrm{hPa}$ in September but accounts for only $13 \%$ of ozone IAV. The emission contribution is smaller in August. In December, both stratospheric input and surface emission influence the IAV of ozone. The contribution from stratospheric input exceeds that from emissions at $270 \mathrm{hPa}$ and becomes slightly weaker at $430 \mathrm{hPa}$. Examining the tagged sources simulation shows that emissions from South and Southeast Asia regions are the 
S. Indian Ocean $\left(40^{\circ} \mathrm{E}-150^{\circ} \mathrm{E}, 45^{\circ} \mathrm{S}-15^{\circ} \mathrm{S}\right)$

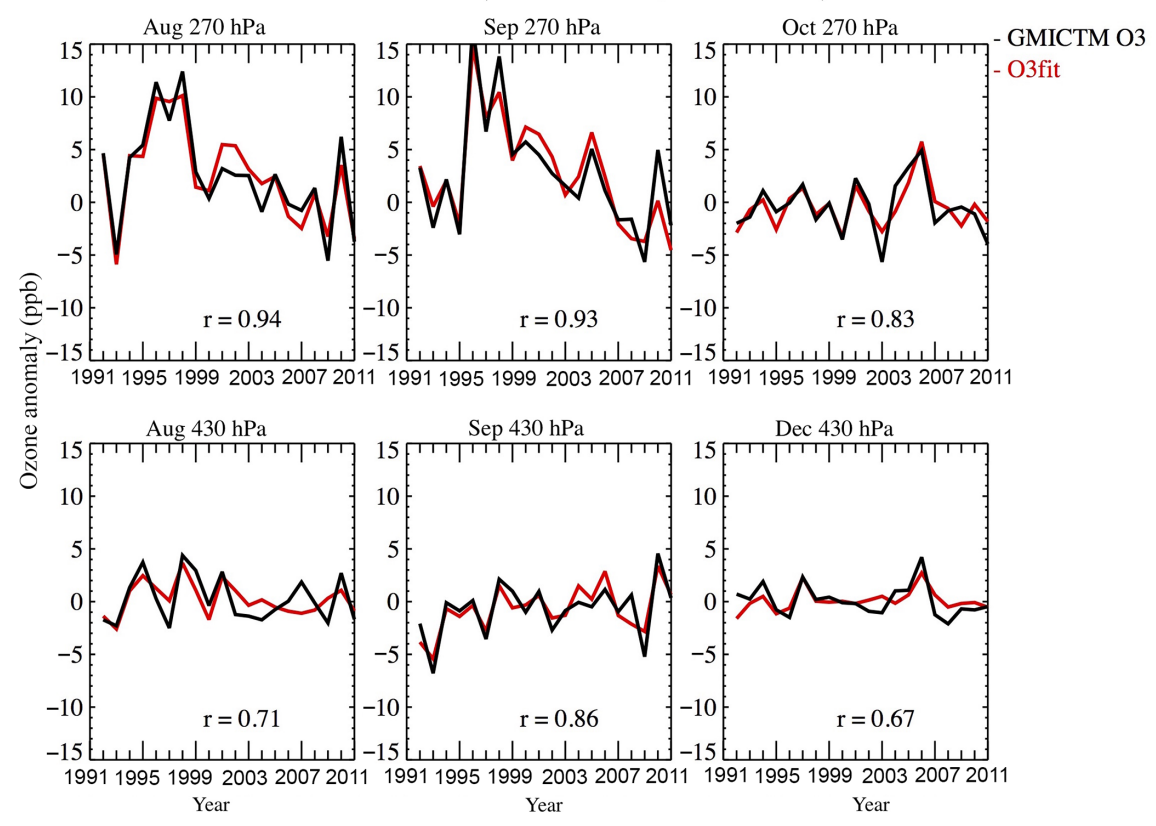

Figure 10. Comparison of the simulated ozone anomalies and the reconstructed ozone anomalies relying on two predictor variables: $\mathrm{StratO}_{3}$ and $\mathrm{Emiss}_{3}$ at 270 and $430 \mathrm{hPa}$ over the South Indian Ocean region. Three panels show results from August (left), September (middle), and December (right) from 1992 to 2011. Unit for $y$ axis is parts per billion (ppb).

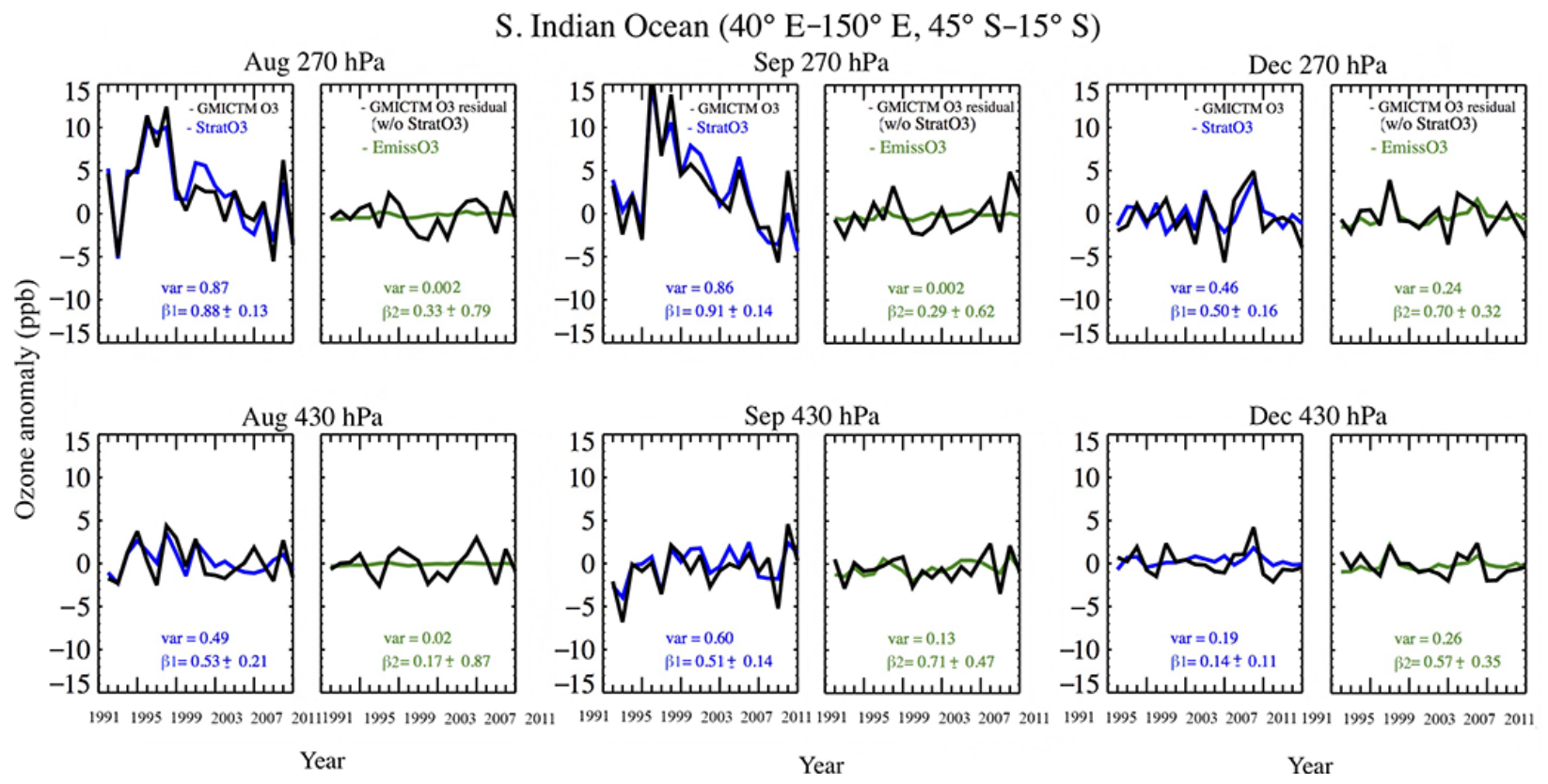

Figure 11. The multi-regression results of simulated ozone anomalies over the South Indian Ocean region relying on two predictor variables: $\mathrm{StratO}_{3}$ (blue) and $\mathrm{EmissO}_{3}$ (green) at 270 and $430 \mathrm{hPa}$. Three panels show results from August (left), September (middle), and December (right) from 1992 to 2011. Each panel contains two columns. The left column of each panel compares the anomalies of StratO 3 (blue) and simulated ozone mixing ratio (black) from the GMI-CTM model at 270 and $430 \mathrm{hPa}$. The right column compares the simulated $\mathrm{O}_{3}$ residual after removing the regression from $\mathrm{StratO}_{3}$ (black line) and $\mathrm{EmissO}_{3}$ (green line) at these two levels. EmissO $\mathrm{S}_{3}$ is calculated from the difference of simulated ozone between the run with yearly-varied emission and the run with constant emission. Unit for $y$ axis is parts per billion ( $\mathrm{ppb})$. The variance explained by each predictor (var), regression coefficient $(\beta)$, and its $95 \%$ confidence level are labeled in each panel. 
S. Indian Ocean $\left(40^{\circ} \mathrm{E}-150^{\circ} \mathrm{E}, 45^{\circ} \mathrm{S}-15^{\circ} \mathrm{S}\right)$
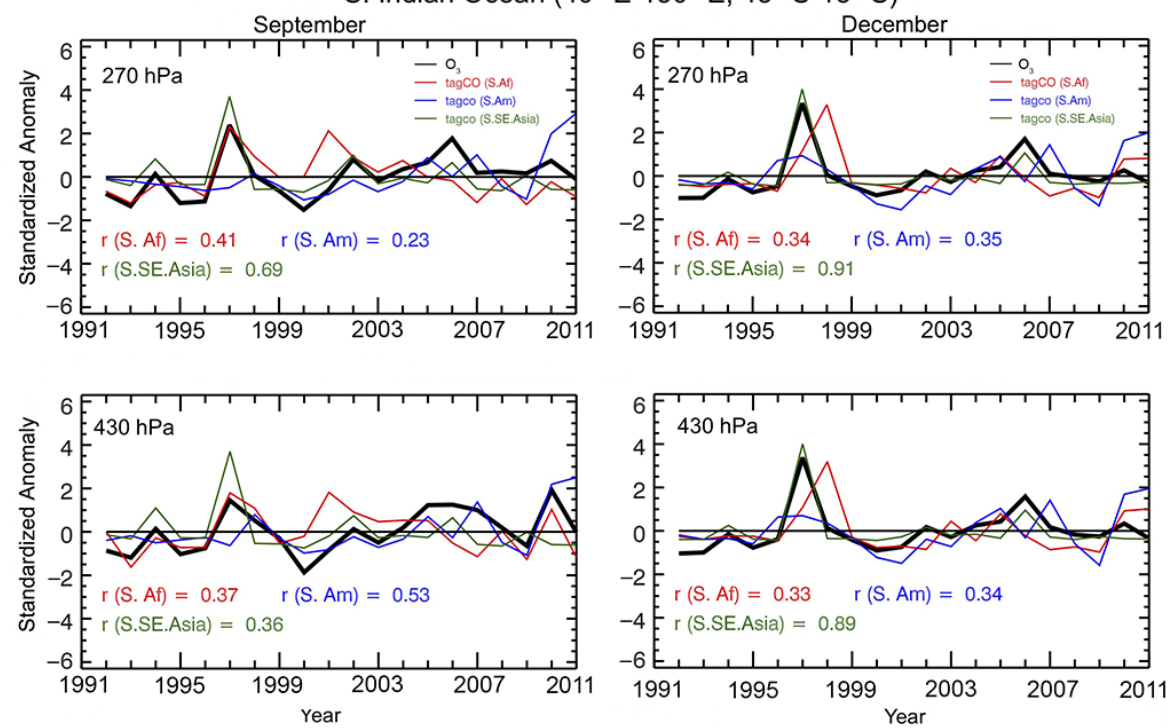

Figure 12. The standardized anomalies of the tagged CO tracers over the South Indian Ocean region from three burning source regions, including southern Africa (red), South America (blue), and South and Southeast Asia (green), and their comparison with the EmissO 3 (black) at 270 and $430 \mathrm{hPa}$ in September and December from 1992 to 2011.

largest source of ozone IAV at 270 and $430 \mathrm{hPa}$ in December, with a stronger influence at the upper troposphere (Fig. 12).

These results show that stratospheric ozone makes a significant contribution to the tropospheric ozone variability over the South Indian Ocean, with the largest influence in the upper troposphere in austral winter. Emission influence from nearby pollution in the boundary layer is relatively weak and only significant in September, 1 month after the southern hemispheric peak-burning season. In the upper troposphere, the cross-Equator transport of pollutants from South and Southeast Asia is the major emission source affecting the ozone variability. The influence peaks in December in the upper troposphere and extends to the middle troposphere.

\subsubsection{Tropical South Atlantic}

In the upper troposphere, lightning produces $\mathrm{NO}_{x}$ and promotes the photochemical ozone production (e.g., Pickering et al., 1993). Murray et al. (2013) shows that the IAV of tropical tropospheric ozone column is sensitive to the IAV of lightning over the tropical South Atlantic region. We therefore add the lightning $\mathrm{NO}_{x}$ as the third variable besides $\mathrm{StratO}_{3}$ and $\mathrm{EmissO}_{3}$. We test whether the addition of lightning $\mathrm{NO}_{x}$ improves the regression model significantly. Figure 13 shows the comparison between simulated and fitted ozone anomalies without and with lightning $\mathrm{NO}_{x}$. During the "dry season" months of August and September, when the subtropical-jet-related STE (Karoly et al., 1998; BalsElsholz et al., 2001; Nakamura and Shimpo, 2004) reaches a seasonal maximum, the lightning activity reaches a seasonal minimum over the Southern Hemisphere. The fitted ozone anomalies based solely on $\mathrm{StratO}_{3}$ and $\mathrm{EmissO}_{3}$ (red) show high correlations ( $r=0.8$ in August, $r=0.74$ in September) with those simulated from GMI-CTM at $270 \mathrm{hPa}$. Agreement between simulated and fitted ozone does not change in August and improves slightly in September by adding lightning $\mathrm{NO}_{x}$ in regression. In September, the simulated ozone anomaly shows a minimum ( $\sim-6 \mathrm{ppb})$ in 2007 and a peak ( 5 ppb) in 2010 at $430 \mathrm{hPa}$, but the IAV from 2007 to 2010 is almost missing in the fitted ozone anomaly, which indicates that other factors drive the IAV of ozone over the tropical South Atlantic during this period. During the "wet season" month of December, the lightning activity reaches its seasonal maximum. Our regression based on $\mathrm{StratO}_{3}$ and EmissO $_{3}$ does not capture well the IAV of GMI-CTM simulated ozone at either level. The fitted ozone reproduces many of the IAV of simulated ozone after including lightning $\mathrm{NO}_{x}$ in the regression, indicating a strong influence from the lightning $\mathrm{NO}_{x}$ in December.

Figure 14 shows the regression results of relative contributions of stratospheric input and surface emission on the IAV of ozone. As discussed above, the tropical South Atlantic is in the descending branch of the Walker Circulation. Therefore, even though this region is located in the tropics, the IAV of stratospheric input still plays a dominant role and explains ozone variance of $60 \%$ in August and $51 \%$ in September in the upper troposphere. The stratospheric contribution, associated with radiative descent over this region, drops to less than $38 \%$ in August and $18 \%$ in September at $430 \mathrm{hPa}$ but is still significant during these 2 months. Emission influence is significant at $430 \mathrm{hPa}$ in August but only accounts for $10 \%$ of ozone variation. Emission contribution is not signifi- 


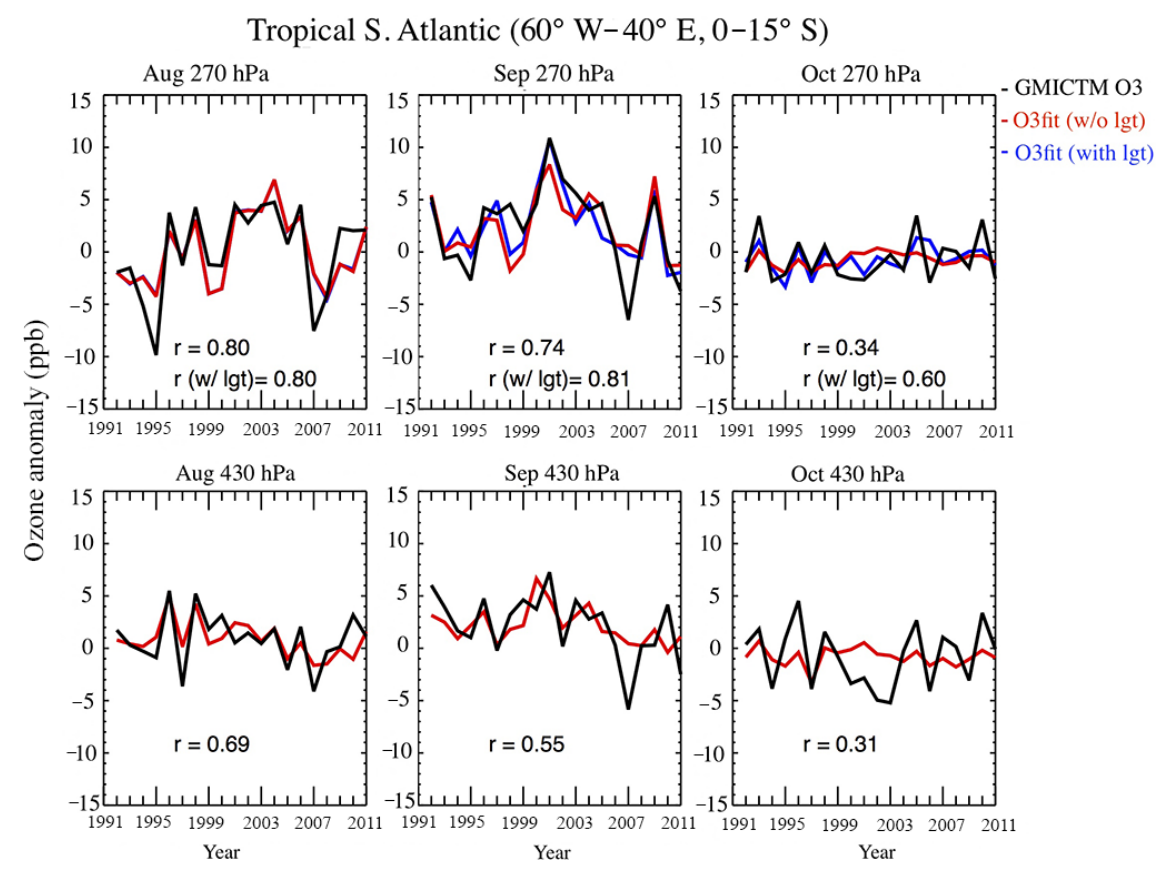

Figure 13. Comparison of the simulated ozone anomalies and the reconstructed ozone anomalies relying on two predictor variables: Strat $\mathrm{O}_{3}$ and $\mathrm{EmissO}_{3}$ (red) over the tropical South Atlantic region at 270 and $430 \mathrm{hPa}$. At $270 \mathrm{hPa}$, the reconstructed ozone anomalies from three predictor variables including lightning $\mathrm{NO}_{x}$ (blue) are added. Three panels show results from August (left), September (middle), and December (right) from 1992 to 2011 . Unit for $y$ axis is parts per billion (ppb).

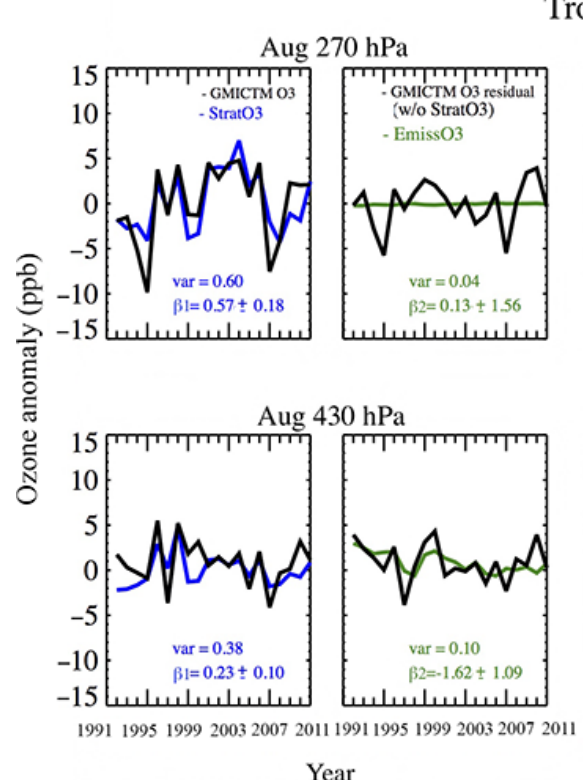

Tropical S. Atlantic $\left(60^{\circ} \mathrm{W}-40^{\circ} \mathrm{E}, 0-15^{\circ} \mathrm{S}\right)$

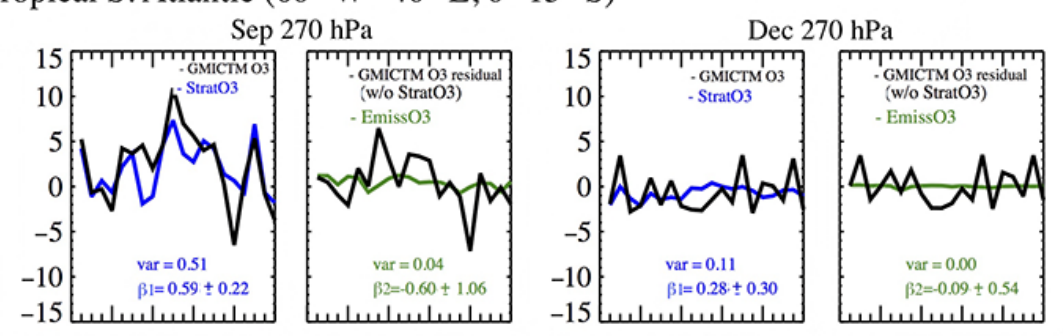

Figure 14. The multi-regression results of simulated ozone anomalies over the tropical South Atlantic region relying on $\mathrm{StratO}_{3}(\mathrm{blue})$ and $\mathrm{EmissO}_{3}$ (green) at 270 and $430 \mathrm{hPa}$. Three panels show results from August (left), September (middle), and December (right) from 1992 to 2011. Each panel contains two columns. The left column of each panel compares the anomalies of $\mathrm{StratO}_{3}$ (blue) and simulated ozone mixing ratio (black) from the GMI-CTM model at 270 and $430 \mathrm{hPa}$. The right column compares the simulated $\mathrm{O}_{3}$ residual after removing the regression from $\mathrm{StratO}_{3}$ (black line) and $\mathrm{EmissO}_{3}$ (green line) at these two levels. EmissO $\mathrm{S}_{3}$ is calculated from the difference of simulated ozone between the run with yearly-varied emission and the run with constant emission. Unit for $y$ axis is parts per billion (ppb). The variance explained by each predictor (var), regression coefficient $(\beta)$, and its $95 \%$ confidence level are labeled in each panel. 
cant at either level in September. Examination of the simulation shows that emission contribution is limited even at lower levels; the emission contribution becomes significant and explains $\sim 30 \%$ variance of ozone at $\sim 700 \mathrm{hPa}$ (not shown). In December, neither stratospheric input nor emission contributes much to the IAV of ozone.

In the model, the lightning emissions take place in connection with deep convective events (Allen et al., 2010). An increase in deep convection produces more upper tropospheric $\mathrm{NO}_{x}$ from lightning, which results in more ozone production. On the other hand, deep convection affects the upper tropospheric ozone budget through its direct transport of surface air. In December, biomass burning in the Southern Hemisphere is at its seasonal minimum. Air over the tropical South Atlantic is relatively clean with low CO (Liu et al., 2010). Deep convection over a clean region reduces upper tropospheric ozone by mixing up ozone-poor air from near the surface. This effect could be opposite if deep convection happens over a polluted region with relatively high ozone and its precursors (Lawrence et al., 2003; Ziemke et al., 2015). Use of the correlation to identify influence from the lightning $\mathrm{NO}_{x}$ does not separate the two outcomes of IAV in convection; thus the sign of the correlation between variations in lightning $\mathrm{NO}_{x}$ and upper tropospheric ozone can be positive or negative. The correlation is positive if the contribution from lightning $\mathrm{NO}_{x}$ exceeds the contribution from convective transport or if transport of polluted air increases ozone. The correlation is negative if transport of clean air overwhelms ozone production from lightning $\mathrm{NO}_{x}$. Figure 15 compares the model residual after removing the contributions from $\mathrm{StratO}_{3}$ and $\mathrm{EmissO}_{3}$ with the lightning $\mathrm{NO}_{x}$ at $270 \mathrm{hPa}$ in September and December. In September the IAV of lightning plays a minor but significant role in the IAV of ozone in the upper troposphere. In December, the changes in lightning $\mathrm{NO}_{x}$ have a significant impact on the ozone IAV, but show a negative regression $\left(\beta_{3}=-1.29\right)$, which indicates that the transport and mixing of clean surface air exceeds ozone production from lightning $\mathrm{NO}_{x}$ emissions with a net negative impact of IAV in convection.

\subsubsection{Tropical southeastern Pacific}

Figures 16, 17, and 18 show the similar comparisons but over the tropical southeastern Pacific region. The fitted ozone anomalies show moderate but still significant correlations with those simulated from GMI-CTM in August and September. In December, the fitted ozone IAV agrees very well with the GMI-CTM simulated ozone IAV at $270 \mathrm{hPa}$. At $430 \mathrm{hPa}$ the agreement collapses and the fitted ozone does not show strong IAV as seen in the GMI-CTM-simulated ozone (Fig. 16). Figure 17 shows that IAV in stratospheric input significantly affects the ozone IAV during these 3 months, explaining $28-40 \%$ of the variance of simulated ozone at $270 \mathrm{hPa}$. Emission contribution is quite small in August and September, but is significant and explains $17 \%$ of simulated
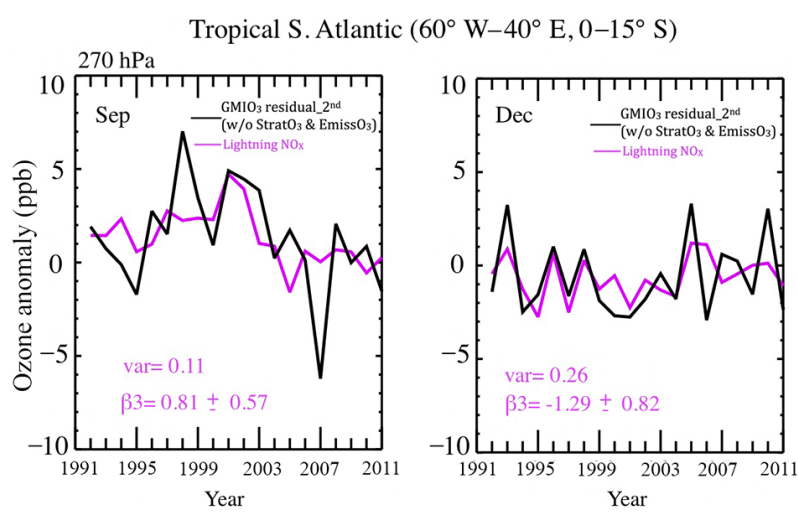

Figure 15. The comparison between regression of lightning $\mathrm{NO}_{x}$ (magenta) and the ozone residual after removing the regression of $\mathrm{StratO}_{3}$ and $\mathrm{EmissO}_{3}$ (black) at $270 \mathrm{hPa}$ in September (left) and December (right) over the tropical South Atlantic region. The increased variance explained by the regression by adding lightning $\mathrm{NO}_{x}$ (var), regression coefficient $(\beta)$, and its $95 \%$ confidence level are labeled in each panel.

ozone IAV in December at $270 \mathrm{hPa}$. The tagged CO simulations show that the tropical southeastern Pacific region is influenced by nearby pollutants from South America, and also by the cross-Equator transport of pollutants from South and Southeast Asia (Fig. 18). Previous studies (e.g., Chandra et al., 1998, 2002, 2009; Sudo and Takahashi, 2001; Ziemke and Chandra, 2003; Doherty et al., 2006; Oman et al., 2011) show that ENSO has its strongest impact in the tropical Pacific basin. In August, the inter-tropical convergence zone is located at its northernmost location north of the Equator. A radiative sinking motion still dominates over the tropical southeastern Pacific in the middle-upper troposphere (Liu et al., 2010). Therefore, the emission contribution from South America is quite small at 430 and $270 \mathrm{hPa}$, as shown in Fig. 17. During an El Niño year, warmer SST with increased convection and large-scale upwelling begin in August, inhibiting the radiative sinking motion and resulting in an ozone decrease in the middle-upper troposphere over this region. Our comparison shows strong negative correlation in August between IAV of middle-upper tropospheric ozone anomalies over this region and Niño 3.4 index during the past 20 years (Fig. 19).

\section{Summary and discussion}

Both model simulations and GEOS-5 assimilated ozone product derived from OMI/MLS show a tropospheric ozone column maximum centered over the South Atlantic from the Equator to $30^{\circ} \mathrm{S}$. This ozone maximum extends westward to South America and the eastern equatorial Pacific; it extends southeastward to southern Africa and the South Indian Ocean. In this study, we use hindcast simulations from the GMI-CTM, driven by assimilated MERRA meteorological 
Tropical S. E. Pacific $\left(150^{\circ} \mathrm{W}-60^{\circ} \mathrm{W}, 0-20^{\circ} \mathrm{S}\right)$

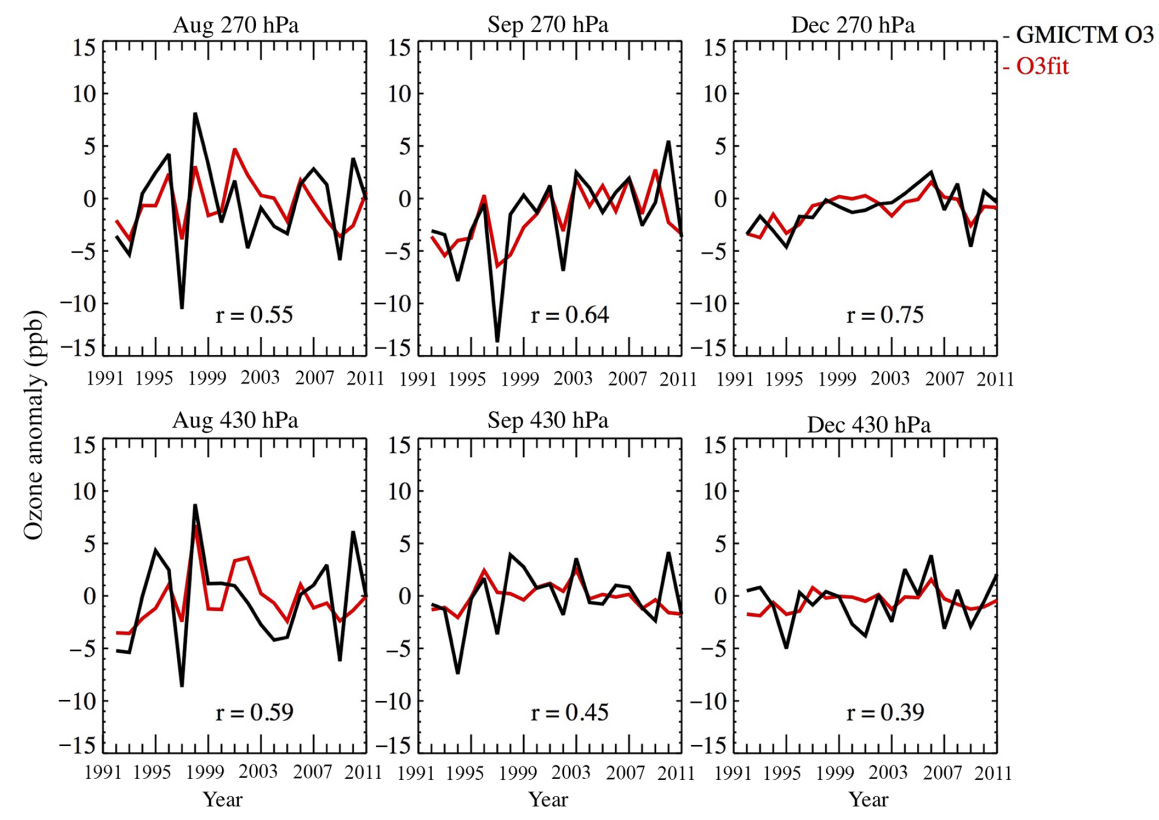

Figure 16. Comparison of the simulated ozone anomalies and the reconstructed ozone anomalies relying on two predictor variables: $\mathrm{StratO}_{3}$ and $\mathrm{EmissO}_{3}$ at 270 and $430 \mathrm{hPa}$ over the tropical southeastern Pacific. Three panels show results from August (left), September (middle), and December (right) from 1992 to 2011. Unit for $y$ axis is parts per billion (ppb).

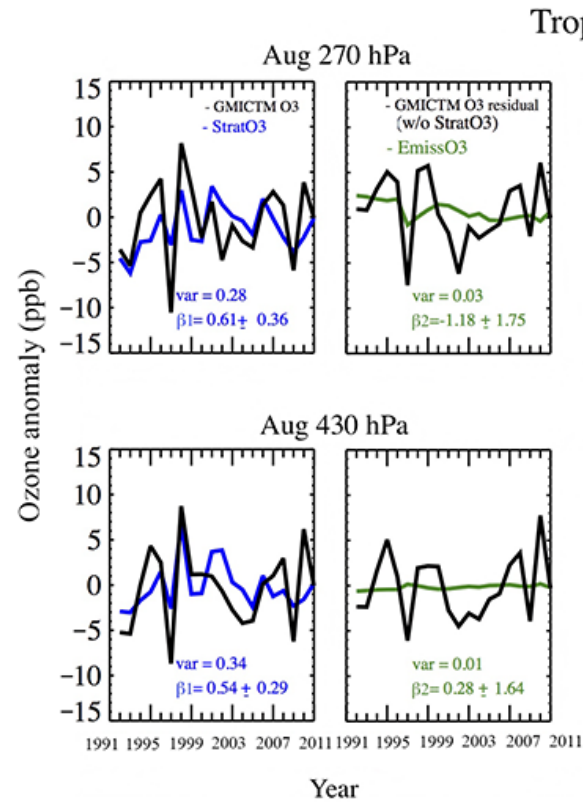

Tropical S. E. Pacific $\left(150^{\circ} \mathrm{W}-60^{\circ} \mathrm{W}, 0-20^{\circ} \mathrm{S}\right)$
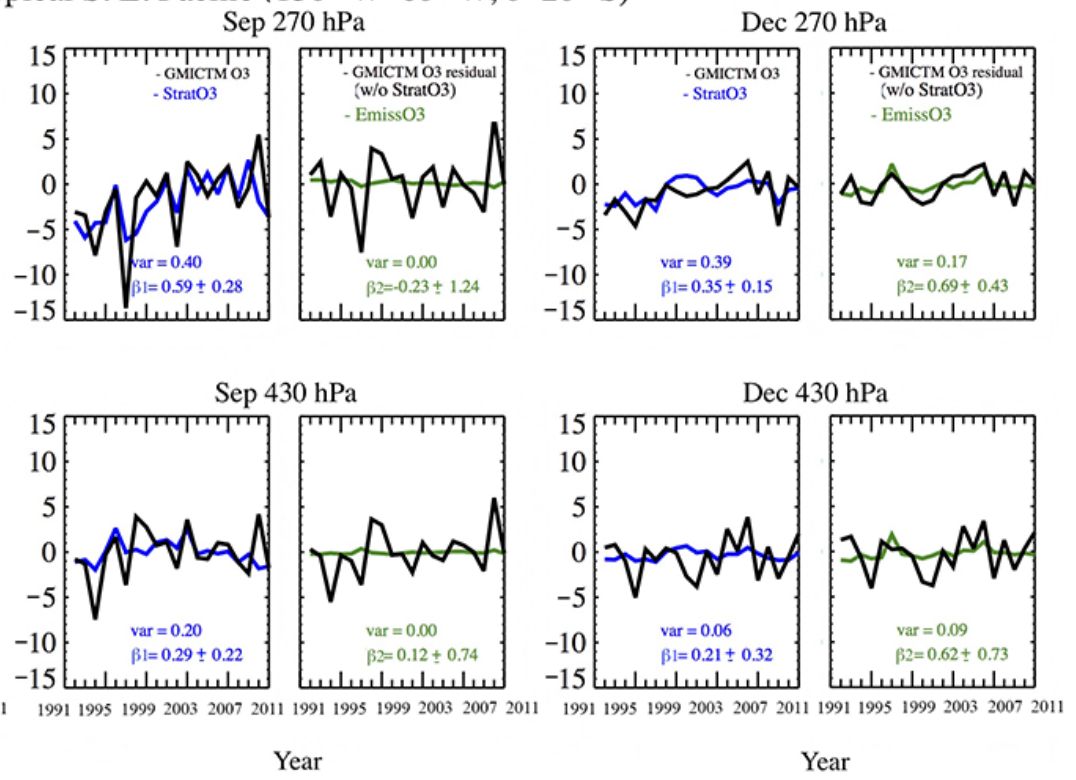

Figure 17. The multi-regression results of simulated ozone anomalies over the tropical southeastern Pacific region relying on two predictor variables: $\mathrm{StratO}_{3}$ (blue) and $\mathrm{EmissO}_{3}$ (green) at 270 and $430 \mathrm{hPa}$. Three panels show results from August (left), September (middle), and December (right) from 1992 to 2011. Each panel contains two columns. The left column of each panel compares the anomalies of StratO 3 (blue) and simulated ozone mixing ratio (black) from the GMI-CTM model at 270 and $430 \mathrm{hPa}$. The right column compares the simulated $\mathrm{O}_{3}$ residual after removing the regression from $\mathrm{StratO}_{3}$ (black line) and $\mathrm{EmissO}_{3}$ (green line) at these two levels. EmissO $\mathrm{O}_{3}$ is calculated from the difference of simulated ozone between the run with yearly-varied emission and the run with constant emission. Unit for $y$ axis is parts per billion (ppb). The variance explained by each predictor (var), regression coefficient $(\beta)$, and its $95 \%$ confidence level are labeled in each panel. 
Tropical S.E. Pacific $\left(150^{\circ} \mathrm{W}-60^{\circ} \mathrm{W}, 0-20^{\circ} \mathrm{S}\right)$
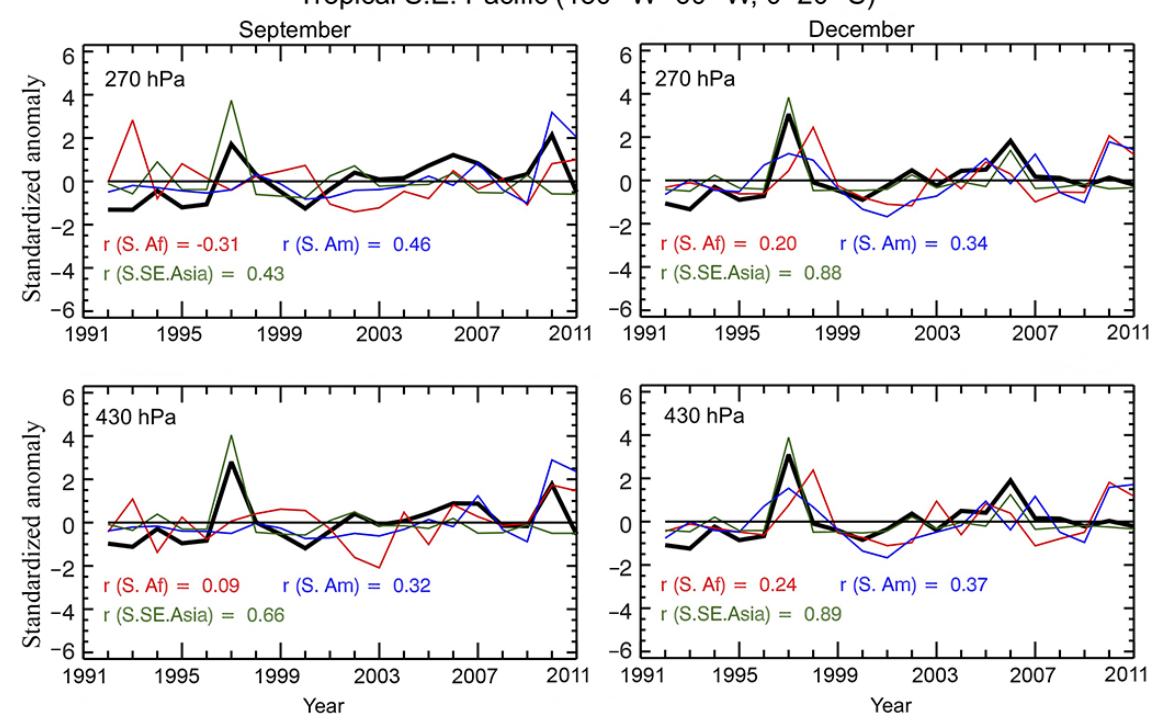

Figure 18. The standardized anomalies of the tagged $\mathrm{CO}$ tracers over the tropical southeastern Pacific region from three burning regions, including southern Africa (red), South America (blue), and South and Southeast Asia (green), and their comparison with the Emiss $\mathrm{O}_{3}$ (black) at 270 and $430 \mathrm{hPa}$ in September and December from 1992 to 2011.

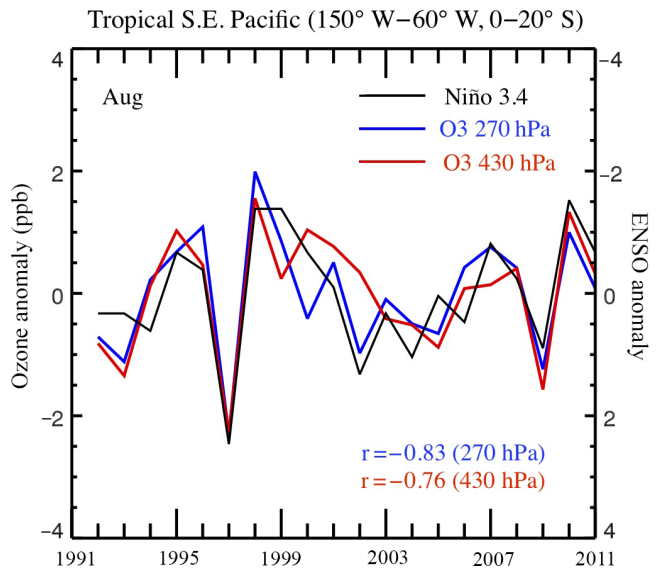

Figure 19. Comparison of IAV of ozone anomalies over the tropical southeastern Pacific region at $270 \mathrm{hPa}$ (blue) and $430 \mathrm{hPa}$ (red) with Niño 3.4 index in August from 1992 to 2011. The 2nd $y$ axis for the ENSO anomaly is reversed.

fields, to interpret and quantify the relative importance of the stratospheric input and surface emission to the interannual variations of tropospheric ozone over four sub-regions of the SHTOM from 1992 to 2011. Over the SHTOM region, IAV in the stratospheric contribution is found to be the most important factor driving the IAV of ozone, especially over the upper troposphere, where $\mathrm{O}_{3}$ changes have strong radiative effects (Lacis et al., 1990). The IAV of the stratospheric contribution explains a large portion of variance in the tropospheric ozone, especially during the austral winter season, even over two selected tropical regions. The strong influence of emission on ozone IAV is largely confined to the South Atlantic region in September.

Although the SHTOM looks like a continuous feature in the Southern Hemisphere, our study shows that the relative importance between stratospheric input and surface emissions changes over different sub-regions at different altitudes. Over the two extra-tropical regions, the IAV of stratospheric contribution explains at least $50 \%$ of variance of the tropospheric ozone during its winter season. The IAV of ozone over the South Indian Ocean is dominantly driven by the IAV of stratospheric ozone contribution with little or no influence from surface emissions at 270 and $430 \mathrm{hPa}$. Over the South Atlantic region, besides the stratospheric ozone input, the IAV of surface emissions from South America and southern Africa also play a big role in the IAV of ozone, especially in the lower levels. The influence from emission exceeds that from the stratospheric contribution on the ozone variability in September at $430 \mathrm{hPa}$. In December, the emission influence, mainly from remote transport of pollutants from South and Southeast Asia, is significant and stays high in the upper troposphere.

Compared to the extra-tropical regions, the influence from stratospheric input is smaller but still significant in two tropical regions at both 270 and $430 \mathrm{hPa}$ in August and September. Over the tropical South Atlantic region, the IAV of stratospheric input plays a dominant role and explains the ozone IAV of $60 \%$ in August and $51 \%$ in September at $270 \mathrm{hPa}$. The stratospheric contribution is still significant at $430 \mathrm{hPa}$, but drops to less than half of that at $270 \mathrm{hPa}$. Emission contributions are not significant at these two levels, even during September. Our model shows that the IAV of ozone is 
partially driven by the IAV of lightning in September. In December, the changes in lightning $\mathrm{NO}_{x}$ have a significant impact on the ozone IAV, but show a negative correlation, which indicates that the transport and mixing of clean surface air exceeds ozone production from lightning $\mathrm{NO}_{x}$ emissions with a net negative impact of IAV in convection. Over the tropical southeastern Pacific, IAV in stratospheric input significantly affects the ozone IAV during these 3 months, explaining $28-40 \%$ of the variance of simulated ozone at $270 \mathrm{hPa}$. Emissions have little or no influence in August and September at 270 and $430 \mathrm{hPa}$, but are significant in December at $270 \mathrm{hPa}$, explaining $17 \%$ of simulated ozone IAV. A further comparison of ozone and the ENSO index shows that ENSO, which affects the tropical convection and large-scale upwelling, shows a strong negative correlation with the IAV of tropospheric ozone over this region. Therefore, the model simulations and/or predictions with different convective parameterizations exhibit large uncertainties over this region, as observed in Stevenson et al. (2006) and Young et al. (2013).

In this study, our regional analysis based on the GMI-CTM model provides valuable conclusions on drivers of interannual variability over different sub-regions of the SHTOM and how they vary with the altitude. The quantification of their relative contributions on interannual timescales enhances our understanding of the IAV and, potentially, long-term trends in the tropospheric ozone, as well as their effects on the radiative forcing of climate.

Data availability. All model output used for this article can be obtained by contacting J. Liu (email: junhua.liu@ nasa.gov).

\section{The Supplement related to this article is available online at doi:10.5194/acp-17-3279-2017-supplement.}

Competing interests. The authors declare that they have no conflict of interest.

Acknowledgements. I gratefully acknowledge the financial support from NASA's Atmospheric Chemistry Modeling and Analysis Program (ACMAP) (grant NNH12ZDA001N). Work was performed under contract with NASA at the Goddard Space Flight Center. I would like to thank K. Pickering, L. Oman, A. Thompson, and H. Liu for their helpful discussion.

Edited by: K. Carslaw

Reviewed by: two anonymous referees

\section{References}

Allen, D., Pickering, K., Duncan, B., and Damon, M.: Impact of lightning NO emissions on North American photochemistry as determined using the Global Modeling Initiative (GMI) model, J. Geophys. Res.-Atmos., 115, D22301, doi:10.1029/2010jd014062, 2010.

Bals-Elsholz, T. M., Atallah, E. H., Bosart, L. F., Wasula, T. A., Cempa, M. J., and Lupo, A. R.: The wintertime Southern Hemisphere split jet: Structure, variability, and evolution, J. Climate, 14, 4191-4215, doi:10.1175/15200442(2001)014<4191:twshsj>2.0.co;2, 2001.

Bjerknes, J.: Atmospheric teleconnections from the equatorial Pacific, Mon. Weather Rev., 97, 163-172, 1969.

Chandra, S., Ziemke, J. R., Min, W., and Read, W. G.: Effects of 1997-1998 El Nino on tropospheric ozone and water vapor, Geophys. Res. Lett., 25, 3867-3870, doi:10.1029/98gl02695, 1998.

Chandra, S., Ziemke, J. R., Bhartia, P. K., and Martin, R. V.: Tropical tropospheric ozone: Implications for dynamics and biomass burning, J. Geophys. Res.-Atmos., 107, ACH 3-1-ACH 3-17, doi:10.1029/2001jd000447, 2002.

Chandra, S., Ziemke, J. R., Duncan, B. N., Diehl, T. L., Livesey, N. J., and Froidevaux, L.: Effects of the 2006 El Niño on tropospheric ozone and carbon monoxide: implications for dynamics and biomass burning, Atmos. Chem. Phys., 9, 4239-4249, doi:10.5194/acp-9-4239-2009, 2009.

Chen, Y., Randerson, J. T., Morton, D. C., DeFries, R. S., Collatz, G. J., Kasibhatla, P. S., Giglio, L., Jin, Y., and Marlier, M. E.: Forecasting Fire Season Severity in South America Using Sea Surface Temperature Anomalies, Science, 334, 787-791, doi:10.1126/science.1209472, 2011.

Chevan, A. and Sutherland, M.: Hierarchical partitioning, Am. Stat., 45, 90-96, doi:10.2307/2684366, 1991.

Chin, M., Ginoux, P., Kinne, S., Torres, O., Holben, B. N., Duncan, B. N., Martin, R. V., Logan, J. A., Higurashi, A., and Nakajima, T.: Tropospheric aerosol optical thickness from the GOCART model and comparisons with satellite and Sun photometer measurements, J. Atmos. Sci., 59, 461-483, 2002.

Danielsen, E. F.: Stratospheric-Tropospheric Exchange Based on Radioactivity, Ozone and Potential Vorticity, J. Atmos. Sci., 25, 502-518, doi:10.1175/15200469(1968)025<0502:stebor>2.0.co;2, 1968.

Doherty, R. M., Stevenson, D. S., Johnson, C. E., Collins, W. J., and Sanderson, M. G.: Tropospheric ozone and El Nino-Southern Oscillation: Influence of atmospheric dynamics, biomass burning emissions, and future climate change, J. Geophys. Res.-Atmos., 111, D19304, doi:10.1029/2005jd006849, 2006.

Duncan, B. N., Martin, R. V., Staudt, A. C., Yevich, R., and Logan, J. A.: Interannual and seasonal variability of biomass burning emissions constrained by satellite observations, J. Geophys. Res.-Atmos., 108, 4040, doi:10.1029/2002jd002378, 2003.

Duncan, B. N., Strahan, S. E., Yoshida, Y., Steenrod, S. D., and Livesey, N.: Model study of the cross-tropopause transport of biomass burning pollution, Atmos. Chem. Phys., 7, 3713-3736, doi:10.5194/acp-7-3713-2007, 2007.

Eyring, V., Lamarque, J.-F., Hess, P., Arfeuille, F., Bowman, K., Chipperfield, M. P., Duncan, B., Fiore, A., Gettelman, A., Giorgetta, M. A., Granier, C., Kinnison, M. H. D., Kunze, M., Langematz, U., Luo, B., Martin, R., Matthes, K., Newman, P. A., Peter, T., Robock, A., Ryerson, T., Saiz-Lopez, A., Salaw- 
itch, R., Schultz, M., Shepherd, T. G., Shindell, D., Staehelin, J., Tegtmeier, S., Thomason, L., Tilmes, S., Vernier, J.-P., Waugh, D. W., and Young, P. J.: Overview of IGAC/SPARC Chemistry-Climate Model Initiative (CCMI) Community Simulations in Support of Upcoming Ozone and Climate Assessments, in: SPARC Newsletter 40, WMO/SPARC, Zürich, 2013.

Fishman, J., Watson, C. E., Larsen, J. C., and Logan, J. A.: Distribution of tropospheric ozone determined from satellite data, J. Geophys. Res.-Atmos., 95, 3599-3617, doi:10.1029/JD095iD04p03599, 1990.

Folkins, I., Braun, C., Thompson, A. M., and Witte, J.: Tropical ozone as an indicator of deep convection, J. Geophys. Res.-Atmos., 107, ACH 13-1-ACH 13-10, doi:10.1029/2001jd001178, 2002.

Groemping, U.: Two simple estimators of relative importance in linear regression based on variance decomposition - Response, Am. Stat., 61, 282-283, 2007.

Guenther, A., Karl, T., Harley, P., Wiedinmyer, C., Palmer, P. I., and Geron, C.: Estimates of global terrestrial isoprene emissions using MEGAN (Model of Emissions of Gases and Aerosols from Nature), Atmos. Chem. Phys., 6, 3181-3210, doi:10.5194/acp-63181-2006, 2006.

Hess, P. and Mahowald, N.: Interannual variability in hindcasts of atmospheric chemistry: the role of meteorology, Atmos. Chem. Phys., 9, 5261-5280, doi:10.5194/acp-9-5261-2009, 2009.

Hoskins, B. J. and Rodwell, M. J.: A model of the Asian summer monsoon .1. The global-scale, J. Atmos. Sci., 52, 1329-1340, doi:10.1175/1520-0469(1995)052<1329:amotas>2.0.co;2, 1995.

Jacob, D. J., Heikes, B. G., Fan, S. M., Logan, J. A., Mauzerall, D. L., Bradshaw, J. D., Singh, H. B., Gregory, G. L., Talbot, R. W., Blake, D. R., and Sachse, G. W.: Origin of ozone and $\mathrm{NO}_{x}$ in the tropical troposphere: A photochemical analysis of aircraft observations over the South Atlantic basin, J. Geophys. Res.-Atmos., 101, 24235-24250, doi:10.1029/96jd00336, 1996.

Jenkins, G. S. and Ryu, J.-H.: Space-borne observations link the tropical atlantic ozone maximum and paradox to lightning, Atmos. Chem. Phys., 4, 361-375, doi:10.5194/acp-4-361-2004, 2004a.

Jenkins, G. S. and Ryu, J.-H.: Linking horizontal and vertical transports of biomass fire emissionsto the tropical Atlantic ozone paradox during the Northern Hemisphere winter season: climatology, Atmos. Chem. Phys., 4, 449-469, doi:10.5194/acp-4449-2004, 2004b

Jourdain, L., Worden, H. M., Worden, J. R., Bowman, K., Li, Q., Eldering, A., Kulawik, S. S., Osterman, G., Boersma, K. F., Fisher, B., Rinsland, C. P., Beer, R., and Gunson, M.: Tropospheric vertical distribution of tropical Atlantic ozone observed by TES during the northern African biomass burning season, Geophys. Res. Lett., 34, L04810, doi:10.1029/2006gl028284, 2007.

Julian, P. R. and Chervin, R. M.: A study of the Southern Oscillation and Walker Circulation phenomenon, Mon. Weather Rev., 106, 1433-1451, 1978.

Karoly, D. J., Vincent, D. G., and Schrage, J. M.: Meteorology of the Southern Hemisphere, General circulation, Am. Meteorol. Soc., Boston, USA, 1998.

Kim, P. S., Jacob, D. J., Liu, X., Warner, J. X., Yang, K., Chance, K., Thouret, V., and Nedelec, P.: Global ozone-CO correlations from OMI and AIRS: constraints on tropospheric ozone sources,
Atmos. Chem. Phys., 13, 9321-9335, doi:10.5194/acp-13-93212013, 2013.

Kruskal, W.: Relative importance by averaging over orderings, Am. Stat., 41, 6-10, doi:10.2307/2684310, 1987.

Lacis, A. A., Wuebbles, D. J., and Logan, J. A.: Radiative forcing of climate by changes in the verticaldistribution of ozone, J. Geophys. Res.-Atmos., 95, 9971-9981, doi:10.1029/JD095iD07p09971, 1990.

Lawrence, M. G., von Kuhlmann, R., Salzmann, M., and Rasch, P. J.: The balance of effects of deep convective mixing on tropospheric ozone, Geophys. Res. Lett., 30, 1940, doi:10.1029/2003g1017644, 2003.

Lewis, S. L., Brando, P. M., Phillips, O. L., van der Heijden, G. M. F., and Nepstad, D.: The 2010 Amazon Drought, Science, 331, 554-554, doi:10.1126/science.1200807, 2011.

Lin, M., Fiore, A. M., Cooper, O. R., Horowitz, L. W., Langford, A. O., Levy II, H., Johnson, B. J., Naik, V., Oltmans, S. J., and Senff, C. J.: Springtime high surface ozone events over the western United States: Quantifying the role of stratospheric intrusions, J. Geophys. Res.-Atmos., 117, D00V22, doi:10.1029/2012jd018151, 2012.

Liu, J., Logan, J. A., Jones, D. B. A., Livesey, N. J., Megretskaia, I., Carouge, C., and Nedelec, P.: Analysis of CO in the tropical troposphere using Aura satellite data and the GEOS-Chem model: insights into transport characteristics of the GEOS meteorological products, Atmos. Chem. Phys., 10, 12207-12232, doi:10.5194/acp-10-12207-2010, 2010.

Liu, J., Logan, J. A., Murray, L. T., Pumphrey, H. C., Schwartz, M. J., and Megretskaia, I. A.: Transport analysis and source attribution of seasonal and interannual variability of $\mathrm{CO}$ in the tropical upper troposphere and lower stratosphere, Atmos. Chem. Phys., 13, 129-146, doi:10.5194/acp-13-129-2013, 2013.

Liu, J., Rodriguez, J. M., Thompson, A. M., Logan, J. A., Douglass, A. R., Olsen, M. A., Steenrod, S. D., and Posny, F.: Origins of tropospheric ozone interannual variation over Reunion: A model investigation, J. Geophys. Res.-Atmos., 121, 521-537, doi:10.1002/2015jd023981, 2016.

Logan, J. A., Prather, M. J., Wofsy, S. C., and McElroy, M. B.: Tropospheric chemistry - a global perspective, J. Geophys. Res. Oceans, 86, 7210-7254, doi:10.1029/JC086iC08p07210, 1981.

Logan, J. A., Megretskaia, I., Nassar, R., Murray, L. T., Zhang, L., Bowman, K. W., Worden, H. M., and Luo, M.: Effects of the 2006 El Nino on tropospheric composition as revealed by data from the Tropospheric Emission Spectrometer (TES), Geophys. Res. Lett., 35, L03816, doi:10.1029/2007g1031698, 2008.

Martin, R. V., Jacob, D. J., Logan, J. A., Bey, I., Yantosca, R. M., Staudt, A. C., Li, Q. B., Fiore, A. M., Duncan, B. N., Liu, H. Y., Ginoux, P., and Thouret, V.: Interpretation of TOMS observations of tropical tropospheric ozone with a global model and in situ observations, J. Geophys. Res.-Atmos., 107, 4351, doi:10.1029/2001jd001480, 2002.

Murray, L. T., Logan, J. A., and Jacob, D. J.: Interannual variability in tropical tropospheric ozone and $\mathrm{OH}$ : The role of lightning, J. Geophys. Res.-Atmos., 118, 11468-11480, doi:10.1002/jgrd.50857, 2013.

Nakamura, H. and Shimpo, A.: Seasonal Variations in the Southern Hemisphere Storm Tracks and Jet Streams as Revealed in a Reanalysis Dataset, J. Climate, 17, 1828-1844, 2004. 
Neu, J. L., Flury, T., Manney, G. L., Santee, M. L., Livesey, N. J., and Worden, J.: Tropospheric ozone variations governed by changes in stratospheric circulation, Nat. Geosci., 7, 340-344, doi:10.1038/ngeo2138, 2014

Olivier, J. G. J., Van Aardenne, J. A., Dentener, F. J., Pagliari, V., Ganzeveld, L. N., and Peters, J. A. H. W.: Recent trends in global greenhouse gas emissions: regional trends and spatial distribution of key sources, in: Non- $\mathrm{CO}_{2}$ Greenhouse Gases (NCGG-4), edited by: van Amstel, A., Millpress, Rotterdam, 325-330, 2005.

Olsen, M. A., Wargan, K., and Pawson, S.: Tropospheric column ozone response to ENSO in GEOS-5 assimilation of OMI and MLS ozone data, Atmos. Chem. Phys., 16, 7091-7103, doi:10.5194/acp-16-7091-2016, 2016.

Oman, L. D., Ziemke, J. R., Douglass, A. R., Waugh, D. W., Lang, C., Rodriguez, J. M., and Nielsen, J. E.: The response of tropical tropospheric ozone to ENSO, Geophys. Res. Lett., 38, L13706, doi:10.1029/2011g1047865, 2011.

Oman, L. D., Douglass, A. R., Ziemke, J. R., Rodriguez, J. M., Waugh, D. W., and Nielsen, J. E.: The ozone response to ENSO in Aura satellite measurements and a chemistryclimate simulation, J. Geophys. Res.-Atmos., 118, 965-976, doi:10.1029/2012jd018546, 2013.

Pickering, K. E., Thompson, A. M., Tao, W. K., and Kucsera, T. L.: Upper tropospheric ozone production following mesoscale convection during step EMEX, J. Geophys. Res.-Atmos., 98, 87378749, doi:10.1029/93jd00875, 1993.

Pickering, K. E., Thompson, A. M., Wang, Y. S., Tao, W. K., McNamara, D. P., Kirchhoff, V., Heikes, B. G., Sachse, G. W., Bradshaw, J. D., Gregory, G. L., and Blake, D. R.: Convective transport of biomass burning emissions over Brazil during TRACE A, J. Geophys. Res.-Atmos., 101, 23993-24012, doi:10.1029/96jd00346, 1996.

Prather, M. J., Zhu, X., Tang, Q., Hsu, J. N., and Neu, J. L.: An atmospheric chemist in search of the tropopause, J. Geophys. Res.Atmos., 116, D04306, doi:10.1029/2010jd014939, 2011.

Rienecker, M. M., Suarez, M. J., Gelaro, R., Todling, R., Bacmeister, J., Liu, E., Bosilovich, M. G., Schubert, S. D., Takacs, L., Kim, G.-K., Bloom, S., Chen, J., Collins, D., Conaty, A., Da Silva, A., Gu, W., Joiner, J., Koster, R. D., Lucchesi, R., Molod, A., Owens, T., Pawson, S., Pegion, P., Redder, C. R., Reichle, R., Robertson, F. R., Ruddick, A. G., Sienkiewicz, M., and Woollen, J.: MERRA: NASA's Modern-Era Retrospective Analysis for Research and Applications, J. Climate, 24, 3624-3648, doi:10.1175/jcli-d-11-00015.1, 2011.

Rodwell, M. J. and Hoskins, B. J.: Subtropical anticyclones and summer monsoons, J. Climate, 14, 3192-3211, doi:10.1175/1520-0442(2001)014<3192:saasm>2.0.co;2, 2001.

Sauvage, B., Thouret, V., Thompson, A. M., Witte, J. C., Cammas, J. P., Nedelec, P., and Athier, G.: Enhanced view of the "tropical Atlantic ozone paradox" and "zonal wave one" from the in situ MOZAIC and SHADOZ data, J. Geophys. Res.-Atmos., 111, D01301, doi:10.1029/2005jd006241, 2006.

Sauvage, B., Martin, R. V., van Donkelaar, A., and Ziemke, J. R.: Quantification of the factors controlling tropical tropospheric ozone and the South Atlantic maximum, J. Geophys. Res.Atmos., 112, D11309, doi:10.1029/2006jd008008, 2007.

Solomon, S., Thompson, D. W. J., Portmann, R. W., Oltmans, S. J., and Thompson, A. M.: On the distribution and variability of ozone in the tropical upper troposphere: Implications for tropi- cal deep convection and chemical-dynamical coupling, Geophys. Res. Lett., 32, L23813, doi:10.1029/2005g1024323, 2005.

Stevenson, D. S., Dentener, F. J., Schultz, M. G., Ellingsen, K., van Noije, T. P. C., Wild, O., Zeng, G., Amann, M., Atherton, C. S., Bell, N., Bergmann, D. J., Bey, I., Butler, T., Cofala, J., Collins, W. J., Derwent, R. G., Doherty, R. M., Drevet, J., Eskes, H. J., Fiore, A. M., Gauss, M., Hauglustaine, D. A., Horowitz, L. W., Isaksen, I. S. A., Krol, M. C., Lamarque, J. F., Lawrence, M. G., Montanaro, V., Muller, J. F., Pitari, G., Prather, M. J., Pyle, J. A., Rast, S., Rodriguez, J. M., Sanderson, M. G., Savage, N. H., Shindell, D. T., Strahan, S. E., Sudo, K., and Szopa, S.: Multimodel ensemble simulations of present-day and near-future tropospheric ozone, J. Geophys. Res.-Atmos., 111, D08301, doi:10.1029/2005jd006338, 2006.

Stohl, A., Bonasoni, P., Cristofanelli, P., Collins, W., Feichter, J., Frank, A., Forster, C., Gerasopoulos, E., Gaggeler, H., James, P., Kentarchos, T., Kromp-Kolb, H., Kruger, B., Land, C., Meloen, J., Papayannis, A., Priller, A., Seibert, P., Sprenger, M., Roelofs, G. J., Scheel, H. E., Schnabel, C., Siegmund, P., Tobler, L., Trickl, T., Wernli, H., Wirth, V., Zanis, P., and Zerefos, C.: Stratosphere-troposphere exchange: A review, and what we have learned from STACCATO, J. Geophys. Res.-Atmos., 108, 8516, doi:10.1029/2002jd002490, 2003.

Strahan, S. E., Duncan, B. N., and Hoor, P.: Observationally derived transport diagnostics for the lowermost stratosphere and their application to the GMI chemistry and transport model, Atmos. Chem. Phys., 7, 2435-2445, doi:10.5194/acp-7-2435-2007, 2007.

Strahan, S. E., Douglass, A. R., and Newman, P. A.: The contributions of chemistry and transport to low arctic ozone in March 2011 derived from Aura MLS observations, J. Geophys. Res.Atmos., 118, 1563-1576, doi:10.1002/jgrd.50181, 2013.

Strode, S. A., Rodriguez, J. M., Logan, J. A., Cooper, O. R., Witte, J. C., Lamsal, L. N., Damon, M., Van Aartsen, B., Steenrod, S. D., and Strahan, S. E.: Trends and variability in surface ozone over the United States, J. Geophys. Res.-Atmos., 120, 9020-9042, doi:10.1002/2014jd022784, 2015.

Sudo, K. and Takahashi, M.: Simulation of tropospheric ozone changes during 1997-1998 El Nino: Meteorological impact on tropospheric photochemistry, Geophys. Res. Lett., 28, 40914094, doi:10.1029/2001g1013335, 2001.

Thompson, A. M., Pickering, K. E., McNamara, D. P., Schoeberl, M. R., Hudson, R. D., Kim, J. H., Browell, E. V., Kirchhoff, V., and Nganga, D.: Where did tropospheric ozone over southern Africa and the tropical Atlantic come from in October 1992? Insights from TOMS, GTE TRACE A, and SAFARI 1992, J. Geophys. Res.-Atmos., 101, 24251-24278, doi:10.1029/96jd01463, 1996.

Thompson, A. M., Witte, J. C., McPeters, R. D., Oltmans, S. J., Schmidlin, F. J., Logan, J. A., Fujiwara, M., Kirchhoff, V., Posny, F., Coetzee, G. J. R., Hoegger, B., Kawakami, S., Ogawa, T., Johnson, B. J., Vomel, H., and Labow, G.: Southern Hemisphere Additional Ozonesondes (SHADOZ) 1998-2000 tropical ozone climatology - 1. Comparison with Total Ozone Mapping Spectrometer (TOMS) and ground-based measurements, J. Geophys. Res.-Atmos., 108, 8238, doi:10.1029/2001jd000967, 2003.

Thouret, V., Saunois, M., Minga, A., Mariscal, A., Sauvage, B., Solete, A., Agbangla, D., Nédélec, P., Mari, C., Reeves, C. E., and Schlager, H.: An overview of two years of ozone radio sound- 
ings over Cotonou as part of AMMA, Atmos. Chem. Phys., 9, 6157-6174, doi:10.5194/acp-9-6157-2009, 2009.

Tocquer, F., Barret, B., Mari, C., Le Flochmoen, E., Cammas, J. P., and Sauvage, B.: An upper tropospheric 'ozone river' from Africa to India during the 2008 Asian post-monsoon season, Tellus B, 67, 25350, doi:10.3402/tellusb.v67.25350, 2015.

van der Werf, G. R., Randerson, J. T., Giglio, L., Collatz, G. J., Mu, M., Kasibhatla, P. S., Morton, D. C., DeFries, R. S., Jin, Y., and van Leeuwen, T. T.: Global fire emissions and the contribution of deforestation, savanna, forest, agricultural, and peat fires (19972009), Atmos. Chem. Phys., 10, 11707-11735, doi:10.5194/acp10-11707-2010, 2010.

Voulgarakis, A., Savage, N. H., Wild, O., Braesicke, P., Young, P. J., Carver, G. D., and Pyle, J. A.: Interannual variability of tropospheric composition: the influence of changes in emissions, meteorology and clouds, Atmos. Chem. Phys., 10, 2491-2506, doi:10.5194/acp-10-2491-2010, 2010

Voulgarakis, A., Hadjinicolaou, P., and Pyle, J. A.: Increases in global tropospheric ozone following an El Nino event: examining stratospheric ozone variability as a potential driver, Atmos. Sci. Lett., 12, 228-232, doi:10.1002/asl.318, 2011.

Voulgarakis, A., Marlier, M. E., Faluvegi, G., Shindell, D. T., Tsigaridis, K., and Mangeon, S.: Interannual variability of tropospheric trace gases and aerosols: The role of biomass burning emissions, J. Geophys. Res.-Atmos., 120, 7157-7173, doi:10.1002/2014jd022926, 2015.

Wargan, K., Pawson, S., Olsen, M. A., Witte, J. C., Douglass, A. R., Ziemke, J. R., Strahan, S. E., and Nielsen, J. E.: The global structure of upper troposphere-lower stratosphere ozone in GEOS-5: A multiyear assimilation of EOS Aura data, J. Geophys. Res.Atmos., 120, 2013-2036, doi:10.1002/2014jd022493, 2015.

Weller, R., Lilischkis, R., Schrems, O., Neuber, R., and Wessel, S.: Vertical ozone distribution in the marine atmosphere over the central Atlantic Ocean ( $\left.56^{\circ} \mathrm{S} 50^{\circ} \mathrm{N}\right)$, J. Geophys. Res.-Atmos., 101, 1387-1399, doi:10.1029/95jd02838, 1996.

WMO: Scientific Assessment of Ozone Depletion: 2014, Global Ozone Research and Monitoring Project, World Meteorological Organization, Geneva, Switzerland, 2014.
Young, P. J., Archibald, A. T., Bowman, K. W., Lamarque, J.-F., Naik, V., Stevenson, D. S., Tilmes, S., Voulgarakis, A., Wild, O., Bergmann, D., Cameron-Smith, P., Cionni, I., Collins, W. J., Dalsøren, S. B., Doherty, R. M., Eyring, V., Faluvegi, G., Horowitz, L. W., Josse, B., Lee, Y. H., MacKenzie, I. A., Nagashima, T., Plummer, D. A., Righi, M., Rumbold, S. T., Skeie, R. B., Shindell, D. T., Strode, S. A., Sudo, K., Szopa, S., and Zeng, G.: Preindustrial to end 21 st century projections of tropospheric ozone from the Atmospheric Chemistry and Climate Model Intercomparison Project (ACCMIP), Atmos. Chem. Phys., 13, 2063 2090, doi:10.5194/acp-13-2063-2013, 2013.

Zeng, G. and Pyle, J. A.: Influence of El Nino Southern Oscillation on stratosphere/troposphere exchange and the global tropospheric ozone budget, Geophys. Res. Lett., 32, L01814, doi:10.1029/2004g1021353, 2005.

Ziemke, J. R. and Chandra, S.: La Nina and El Nino-induced variabilities of ozone in the tropical lower atmosphere during 19702001, Geophys. Res. Lett., 30, 1142, doi:10.1029/2002g1016387, 2003.

Ziemke, J. R., Chandra, S., Thompson, A. M., and McNamara, D. P.: Zonal asymmetries in southern hemisphere column ozone: Implications of biomass burning, J. Geophys. Res.-Atmos., 101, 14421-14427, doi:10.1029/96jd01057, 1996.

Ziemke, J. R., Chandra, S., Oman, L. D., and Bhartia, P. K.: A new ENSO index derived from satellite measurements of column ozone, Atmos. Chem. Phys., 10, 3711-3721, doi:10.5194/acp10-3711-2010, 2010.

Ziemke, J. R., Olsen, M. A., Witte, J. C., Douglass, A. R., Strahan, S. E., Wargan, K., Liu, X., Schoeberl, M. R., Yang, K., Kaplan, T. B., Pawson, S., Duncan, B. N., Newman, P. A., Bhartia, P. K., and Heney, M. K.: Assessment and applications of NASA ozone data products derived from Aura OMI/MLS satellite measurements in context of the GMI chemical transport model, J. Geophys. Res.Atmos., 119, 5671-5699, doi:10.1002/2013jd020914, 2014.

Ziemke, J. R., Douglass, A. R., Oman, L. D., Strahan, S. E., and Duncan, B. N.: Tropospheric ozone variability in the tropics from ENSO to MJO and shorter timescales, Atmos. Chem. Phys., 15, 8037-8049, doi:10.5194/acp-15-8037-2015, 2015. 